Centro de Estudios Constitucionales de Chile Universidad de Talca

"Apelación, doble instancia y proceso civil oral. A propósito de la reforma en trámite"

Diego I. Palomo Vélez

\title{
APELACIÓN, DOBLE INSTANCIA Y PROCESO CIVIL ORAL. A PROPÓSITO DE LA REFORMA EN TRÁMITE ${ }^{1}$
}

\author{
MOTION TO APPEAL, RIGHT TO HAVING A CONVICTION OR SENTENCE \\ REVIEWED BY A HIGHER COURT AND ORAL CIVIL TRIAL. IN CONSIDERATION \\ OF THE DEVELOPING REFORM
}

\author{
Diego I. Palomo Vélez ${ }^{2}$ \\ Profesor Asociado de Derecho Procesal \\ Universidad de Talca, Chile \\ dpalomo@utalca.cl
}

RESUMEN: En los estudios existentes sobre la reforma procesal civil chilena hay un claro predominio sobre los aspectos ligados con los cambios que deben introducirse en el primer grado de la mano de la apuesta por la oralidad, la inmediación judicial y la concentración de las actuaciones del proceso. El presente articulo se hace cargo de los contenidos del segundo grado jurisdiccional, más concretamente de las posibilidades de mantener un recurso de apelación y la doble instancia en el marco de un modelo procesal civil oral. La tesis de este trabajo opta por sostener la racionalidad, posibilidad y utilidad de contemplar en el nuevo CPC el recurso de apelación y el sistema de doble grado jurisdiccional.

ABSTRACT: In the existing studies on the Chilean civil procedural reform there is a clear predominance over the aspects related to the changes that must be introduced in the first degree throughout orality, immediacy and the concentration of judicial proceedings in the trial. This article deals with the contents of the second jurisdictional degree, more specifically the possibilities of mantaining a motion to appeal and the right to having a conviction or sentence reviewed by a higher court in the context of an oral model of civil procedure. The thesis of this work chooses to sustain the rationality, feasibility and utility of contemplating in the new regulation the motion to appeal and the system of double jurisdictional degree.

PALABRAS CLAVES: Apelación. Doble instancia. Proceso civil oral.

KEY WORDS: Appeal. Right to having a sentence reviewed by a higher court. Oral civil trial.

\footnotetext{
${ }^{1}$ Este trabajo es parte del proyecto Fondecyt $\mathrm{N}^{\circ} 1085321$ titulado "La oralidad en el marco de los cambios que requiere el sistema procesal civil. Sus efectos en la reforma a la justicia civil chilena" (2008-2009), del que quien escribe es responsable. El autor agradece públicamente las valiosas observaciones y aportaciones que respecto del tema recibiera de los profesores Manuel Ortells Ramos y M. Pilar Calderón Cuadrado en su estancia en la Facultad de Derecho de la Universidad de Valencia. Con todo, como es obvio, las opiniones vertidas en este trabajo son de exclusiva responsabilidad del autor. Recibido el 30 de marzo de 2010 y aprobado el 30 de junio de 2010.

${ }^{2}$ Doctor en Derecho, Universidad Complutense de Madrid.
} 


\section{INTRODUCCIÓN: LA COMPLEJA CUESTIÓN DE DETERMINAR}

TODAS LAS CONSECUENCIAS RAZONABLES DE LA OPCIÓN HACIA LA ORALIDAD

CON LA REFORMA PROCESAL CIVIL

El camino hacia un proceso civil oral, con inmediación judicial efectiva y concentración parece no tener mayores dificultades en nuestro país, que en esta materia sólo sigue la clara tendencia evolutiva que ha venido arrojando frutos en distintos países, dejando atrás definitivamente la asociación del proceso oral exclusivamente con el proceso del common law3. De eso dan cuenta no sólo los variados trabajos de nuestra doctrina científica y numerosos foros realizados hasta la fecha, sino también el propio contenido del Proyecto de nuevo CPC que desde mayo del año pasado se encuentra en el Congreso Nacional para su tramitación ${ }^{4}$. No conocemos ninguna opinión seria que al día de hoy sostenga la inconveniencia de avanzar hacia un modelo procesal civil oral.

Con todo, como en toda obra, más si se trata de una obra de envergadura como lo es el diseño y puesta en marcha de un nuevo modelo procesal civil, se pueden distinguir distintas fases o etapas en su construcción. Ocurre que tratándose de nuestro proceso de reforma procesal civil si bien existe un Proyecto de CPC y un consenso general sobre el giro formal que debe tomar el sistema, subsisten diferencias de opinión en algunos aspectos relevantes que cabe definir con sensatez, buen juicio y seriedad por el legislador de turno 5

\footnotetext{
${ }^{3}$ Véase: Taruffo, M. (2006). "El proceso civil de "civil law" y el proceso civil de "common law": aspectos fundamentales" en Sobre las fronteras: escritos sobre la Justicia civil (Bogotá, Ed. Temis), p. 61; TROCKER, N. y VARANO, V. (Editores) (2005). The reforms of civil procedure in comparative perspective (Torino), p. 274.

${ }^{4}$ Este consenso ya había quedado plasmado antes del Proyecto en el informe del Foro para la reforma procesal civil en donde, como primer acuerdo, se consideró necesario "optar decididamente por la oralidad en el procedimiento civil". (2008). "Informe del Foro para la reforma procesal civil", en Revista de Derecho Procesal (Facultad de Derecho de la Universidad de Chile, No 21), p. 11. Véase también al respecto: NúNEzZ OjEDA, R. (2007). "Crónica sobre la reforma del sistema procesal civil chileno (fundamentos, historia y principios)", en De la Oliva Santos, A., Palomo Vélez, D. (coordinadores) Proceso civil: Hacia una nueva Justicia civil (Santiago, Ed. Jurídica de Chile), pp. 684-685. En lo que se refiere al Proyecto propiamente tal, cabe señalar que esta opción hacia la oralidad se refleja no sólo en el Mensaje (No 398-357), sino que también en el hecho de que se recojan expresamente los "principios" de oralidad y sus "principios consecuencia" (inmediación, concentración, publicidad), y que en la propia regulación de los procedimientos declarativos (ordinario y sumario) quede reflejada la técnica procesal ligada a la oralidad denominada modelo de audiencias.

${ }^{5}$ Desde hace un tiempo se percibe una cierta liviandad en la tarea de legislar, como si se tratara de una tarea sencilla. Bien se ha dicho: "Pero cuando legislar se considera fácil -siendo, como es, muy difícil- el proceso legislativo se vicia ya desde su punto de partida: se yerra sobre la naturaleza de lo que se emprende. Y no se actúa ni con respeto a los futuros destinatarios de la norma -en realidad se está comenzando a experimentar con seres humanos vivos- ni con la seriedad propia de quien debiera aprestarse a realizar una ordenación racional, una ordenación de la razón al bien común, según la clásica definición de Tomás de Aquino. Con deformación sustancial de su naturaleza, la ley viene a ser equiparada a las realizaciones materiales no exce-
} 
Pues bien, en relación con estas diferencias de opinión, una de las cuestiones que es y ha sido objeto de debate ${ }^{6}$ es aquélla relativa a la mantención o supresión del recurso de apelación y la doble instancia ${ }^{7}$. Ya en el documento que recoge las Propuestas de bases para redactar un nuevo CPC (Universidad de Chile) existe una referencia, aunque breve, expresa, a la supuesta incompatibilidad del recurso de apelación y la doble instancia con el modelo procesal oral ${ }^{8}$, aunque en el Proyecto de CPC finalmente se recoge un recurso de apelación que permitiría al tribunal superior, de ser aprobado, revisar tanto los hechos como el derecho?.

Por su parte, la doctrina nacional que se ha pronunciado en el tema, tomando como base los planteamientos realizados a propósito de la reforma procesal penal ${ }^{10}$, ya desde hace varios años, ha destacado y asumido la necesidad "ineludible" de lograr establecer un sistema que resulte "compatible", "consistente" y "coherente" técnicamente con las características y particularidades de un modelo procesal oral,

sivamente complicadas. La ley se considera un papel, que ha de publicarse en la Gaceta y cuya aprobación constituye un éxito político, como antaño lo era $-\mathrm{y}$ vuelve a serlo- inaugurar un pantano o un tramo de carretera". De la Oliva Santos, A. (1996). "Las reformas procesales", en Díez-Picazo Giménez, I. (director), Estudios sobre Derecho Procesal (Madrid, Central Hispana, Vol. I), p. 6.

${ }^{6}$ Otro ejemplo está dado por la cuestión de los poderes oficiosos que se pretenden asignar al juez civil en el marco del nuevo modelo procesal. Mientras un sector busca que estos poderes sean mayores en cantidad e intensidad a los contemplados en el Proyecto, otros sostienen que varios de ellos pueden estar en colisión con principios fundamentales del proceso en general y del proceso civil en particular.

${ }^{7}$ El debate no es completamente nuevo ni, desde luego, limitado o circunscrito a la doctrina local. Ejemplo de ello son los trabajos de autores italianos que, a partir de los provocadores planteamientos de Cappelletti, intentaron hacerse cargo de esta cuestión: Pizzorusso, A. (1978). "Sul principio del doppio grado di giurisdizione”, en Rivista di Diritto Processuale, pp. 33-58; RICCI, E. (1978). "Il doppio grado di giurisdizione nel processo civile", en Rivista di diritto processuale, pp. 59-84; Allorio, E. (1979). "Sul doppio grado del proceso civile”, en Studi in onore di Enrico Tulio L. (Milano, Giuffré Editore, T. III), pp. 1783-1812.

${ }^{8}$ Como ha señalado uno de los profesores que integró la Comisión de trabajo, existió consenso sobre la necesidad de avanzar hacia la supresión del recurso de apelación como medio de impugnación de las sentencias definitivas, pero las dudas sobre la composición de los futuros tribunales civiles (colegiados o unipersonales) reavivó el debate, dejándose entregada al Foro la decisión entre los dos modelos. NúNEzZ OjedA, R. (2008). "El sistema de recursos procesales en el ámbito civil en un estado democrático deliberativo", en Revista Ius et Praxis (Año 14, No 1), p. 221. Véase también al respecto: (2005). "Propuesta de Bases para redactar un nuevo CPC para la República de Chile", en Revista de Derecho Procesal (Facultad de Derecho de la Universidad de Chile, No 20), p. 462.

9 La propuesta recogida en el Proyecto da cuenta de uno de los acuerdos del Foro para la reforma procesal civil. "Informe" (2008), p. 22.

${ }^{10}$ Sobre la desaparición de la segunda instancia como protección de la oralidad y objetivo del sistema de recursos en el proceso penal, véase, entre otros: CARocca Pérez, A. (2000). "Recursos en el nuevo sistema procesal penal”, en Carocca Pérez, A. y otros Nuevo Proceso Penal (Santiago, Editorial Jurídica ConoSur), pp. 298-300 y 308-309; Duce, M. y Riego, C. (2007). Proceso penal (Santiago, Ed. Jurídica de Chile), pp. 503-515. 
cambiando el "paradigma tradicional" imperante en esta materia y salvando por tanto este "gran escollo dogmático"11. Esa compatibilidad, consistencia y coherencia se obtendría sólo con la supresión de la doble instancia y la regulación de un recurso extraordinario circunscrito a la revisión de la aplicación del Derecho ${ }^{12}$, sin poder alterar la base fáctica de la decisión del tribunal, condición indispensable para poder conciliar el sistema recursivo con los "principios del derecho procesal moderno"'3.

En este trabajo desarrollamos nuestra posición frente a este relevante problema ligado a la implantación de la oralidad en materia civil, postura que toma distancia de la sustentada por la dogmática nacional, toda vez que no visualizamos una situación insalvable que impida contemplar el recurso de apelación o el sistema de doble instancia en el nuevo modelo procesal civil oral. Al contrario, sostenemos que la decisión de su supervivencia en el nuevo modelo se justifica por varias razones que explicaremos y es perfectamente posible sin gran atentado contra los pilares de la oralidad. Derechamente, somos de la opinión que suprimir la doble instancia en materia procesal civil constituiría un retroceso innegable del sistema de garantías que los ciudadanos actualmente poseen en materia procesal civil ${ }^{14}$, incurriendo en lo que un autor calificaría como la concreción de una reformatio in peius ${ }^{15}$.

Añadidamente, teniendo presente que el modelo de la oralidad es una opción procesal costosa, por los mayores recursos económicos y constantes inversiones que exige al Estado su implementación adecuada ${ }^{16}$, en un país como el nuestro, en

\footnotetext{
${ }^{11}$ Véanse, entre otros: NúNezz OjedA, R. (2008), pp. 199-223; Meneses Pacheco, C. (2009a). "La reforma procesal civil en Chile: Observaciones críticas sobre la organización del primer nivel jurisdiccional”, en Carrasco Poblete, J. (editor) La reforma procesal civil en Chile: Análisis crítico del Anteproyecto de CPC (Santiago, Universidad de los Andes, Cuadernos de Extensión Jurídica 16), pp. 42-44; DuCE, M., Marín, F. y Riego, C. (2008). "Reforma a los procesos civiles orales: consideraciones desde el debido proceso y calidad de la información", en CABEZÓN, A. (Coordinador) Justicia Civil: Perspectivas para una reforma en América Latina (Santiago, CEJA), pp. 13-94 [fecha de consulta: 25 de enero de 2010]. Disponible en: http://www. cejamericas.org/doc/proyectos/Justiciacivil2008_ceja.pdf

${ }^{12}$ WACH, A. (2006). "El sistema de recursos", en Conferencias sobre la Ordenanza procesal civil alemana (Lima, ARA Editores), p. 250.

${ }^{13}$ En este sentido véase: Toro Justiniano, C. (2009). El debido proceso penal: Un estudio desde el prisma de la dogmática procesal penal y la jurisprudencia de la Corte Interamericana de Derechos Humanos (Santiago, Ediciones Jurídicas de Santiago), pp. 120-121.

${ }^{14}$ De la Oliva Santos, A. (1997). "El derecho a los recursos. Los problemas de la única instancia”, en Revista Tribunales de Justicia (No 101), p. 975.

${ }^{15}$ De la Oliva Santos, A. (1996), p. 19.

${ }^{16}$ En este sentido, véase: BONET NAVARRO, J. (2009a). La prueba en el proceso civil: cuestiones fundamentales (Madrid, Difusión jurídica), pp. 59-60.
} 
vías de desarrollo desde hace tiempo, en crisis desde el punto de vista económico por las razones por todos conocidas, con necesidades mucho más urgentes que atender, lo que le corresponde hacer a un legislador responsable más que buscar respetar escrupulosamente la técnica procesal recursiva que se asocia, como si de un matrimonio se tratara, a un modelo oral, es preguntarse hasta qué punto pueden llevarse sus consecuencias (o marcas).

En definitiva, y en la dirección de buscar una respuesta adecuada, razonable y garantista debe descartarse, a nuestro juicio, la alternativa de suprimir la apelación y la doble instancia, dejando a un lado la idea excesivamente dogmática de que el único tipo de recurso posible en un modelo procesal oral es aquel extraordinario que permite una revisión exclusivamente jurídica y proscribe un control de las conclusiones fácticas. Justificamos en las líneas que siguen la posibilidad de convivencia entre la opción por la oralidad e inmediación judicial y todo lo que implica un sistema de doble instancia razonable y el recurso de apelación, confiando, como bien se ha destacado, en que la técnica legislativa procesal asegure un adecuado equilibrio entre la opción por la oralidad, la inmediación y la doble instancia, en definitiva, entendiendo al recurso no tanto como control jerárquico sino que como una garantía de los justiciables ${ }^{17}$, un adecuado equilibrio entre la aspiración de decisiones jurisdiccionales prontas y la búsqueda de mayor calidad y justicia en la decisión ${ }^{18}$, que es la cuestión central de toda la discusión.

\section{LA PARTICULARIDAD DE UN MODELO ORAL: LA INMEDIACIÓN JUDICIAL EFECTIVA}

a) Significados del proceso oral: cuidado, otra vez, con confundir formas procesales con verdaderos principios

En el afán de lograr situar e imponer la opción de la oralidad en reemplazo de la escritura absolutamente predominante en los sistemas procesales, a la cual se responsabilizaba de todos los males de la Justicia civil, se cometieron (y se siguen

\footnotetext{
${ }^{17}$ GonzÁlez Castro, M. (2004). El derecho al recurso en el Pacto de San José de Costa Rica (Córdoba, Editora Lerner), pp. 21-22.

${ }^{18}$ Couture, E. (2002). Fundamentos del Derecho procesal civil, 4ª Edición (Buenos Aires, Ed. B de F), pp. 141 142. En el mismo sentido, véase: Pereira Anabalón, H. (1999). "Oralidad e instancia única o doble en el proceso penal”, en Revista Gaceta Jurídica (No 233), p. 16. Pereira, refiriéndose a la reforma procesal penal, señaló: "Ha sido cuestionada la existencia del recurso de apelación por quienes observan que la mayor expedición y celeridad del proceso requiere de una sola instancia y que no hay razón de lógica jurídica para atribuir mayor valor a la decisión del juez de la alzada que el que tiene el fallo del juez inferior; pero no reparan en que el proceso no solamente requiere decisiones prontas sino también -y especialmente- resoluciones justas, justicia que se satisface mejor con la revisión del fallo de primer grado por el fallo de segundo grado, siendo además muy relevante la percepción de la comunidad, del pueblo en general, en orden a que el sistema judicial se organiza para satisfacer a cabalidad ese trascendente valor".
} 
cometiendo) excesos y errores que conviene evitar en el proceso de reforma que estamos abordando en Chile. Bien se ha dicho que, transcurrido ya más de un siglo desde el comienzo de la verdadera cruzada sostenida en su favor (pensamos en Chiovenda fundamentalmente ${ }^{19}$, aunque no solamente ${ }^{20}$ ), y existiendo ya algunos que a la luz de los resultados obtenidos comienzan a destacar ya no las ventajas sino que los problemas que puede presentar su implementación ${ }^{21}$, en el tema de la oralidad es necesario desmitificar y reubicar ${ }^{22}$ para lograr un correcto entendimiento de aquellas combinaciones que cabe realizar aún en un contexto procesal que apuesta por ésta. Sobre los mitos asociados a la idea de la oralidad la mejor doctrina ya viene advirtiendo hace un tiempo, instando a un abordaje más sensato de esta cuestión, esquivando planteamientos maniqueos que pongan a la oralidad como una especie de panacea que resolvería todas las dificultades del proceso civil ${ }^{23}$. La ubicación que se ha asignado a la oralidad y escritura dentro

\footnotetext{
${ }^{19}$ Por su actividad realizada desde principios del siglo pasado hasta los años 20 Chiovenda es identificado como un "apóstol de la oralidad", asignándosele responsabilidad en la propagación de un verdadero mito en torno a ella. En él la forma oral alcanza niveles cercanos a la de un verdadero dogma formal, respecto del cual asume una declarada defensa. En efecto, comprometido por la adecuación del Código Procesal Civil italiano de 1865 a las condiciones de la sociedad y cultura de su época, protagonizó una campaña reformadora centrada en destacar al proceso oral como el mejor de todos los posibles, y el más conforme con la naturaleza y exigencias de la vida moderna que, sin comprometer las bondades intrínsecas de la justicia, la proporciona y asegura más económicamente, más simplemente y más prontamente. Chiovenda -en su entusiasmo- sitúa a la oralidad al nivel de verdadera panacea para los principales males que arrastra el proceso civil. "La experiencia derivada de la historia permite añadir aún que el proceso oral es el mejor y más conforme con la naturaleza y las exigencias de la vida moderna, porque sin comprometer en lo más mínimo, antes bien, garantizando, la bondad intrínseca de la justicia, la proporciona más económicamente, más simplemente y prontamente". Chiovenda, J. (1977). Principios de Derecho Procesal Civil (Madrid, Ed. Reus, Tomo II), p. 132.

${ }^{20}$ Como destacó Cappelletti, el Código de Hannover de 1850 adoptó el "principio" de la inexistencia jurídica de los actos escritos". Cappelletti, M. (1972). La oralidad y las pruebas en el proceso civil (Traducc. Santiago Sentís Melendo, Buenos Aires, Ediciones Jurídicas Europa América), p. 86.
}

${ }^{21}$ Nieva Fenoll, J. (2007a). “Los problemas de la oralidad”, en Revista Justicia (No 1-2), pp. 101-130. Véase también en: Nieva Fenoll, J. (2008). “The disaventages of orality”, en Carpi, F. y Ortells, M. (editores) Oralidad y escritura en un proceso civil eficiente (Valencia, Universidad de Valencia, Tomo II), pp. 471-473. Véase también: Nieva Fenoll, J. (2007b). "La oralidad en la Ley de Enjuiciamiento Civil: ¿Se ha generado superficialidad y precipitación en la elaboración de las resoluciones judiciales?”, en Revista Justicia (No 3-4), pp. 42-44.

${ }^{22}$ Montero Aroca, J. (2007). "La oralidad en el modelo garantista del proceso civil", en De la Oliva Santos, A., Palomo Vélez, D. (coordinadores) Proceso civil: Hacia una nueva Justicia civil (Santiago, Ed. Jurídica de Chile).

${ }^{23}$ Es que -como ha dicho De la Oliva-si bien sobre la oralidad en el proceso civil han corrido caudalosos ríos de tinta, "estos cursos fluviales poco o nada han fecundado ni la teoría ni la realidad procesales". "Especialmente inuitiles y tediosas consideraba y sigo considerando las apologias genéricas de la oralidad frente a la escritura, con tintes 
del sistema procesal también ha venido planteando problemas y confusiones; en especial, desde el momento que producto del entusiasmo generado en favor de la primera se la ha contemplado como si se tratara de un verdadero principio del proceso sin el cual no puede respetarse la esencia de la idea de proceso. En otras palabras, y con cierto fundamentalismo ${ }^{24}$, que si el juicio no es oral no se estaría respetando la garantía constitucional del debido proceso ${ }^{25}$. La cuestión es importante y debe despejarse antes de continuar con estas líneas si se quiere terminar con la confusión y sus consecuencias.

El proceso es una realidad artificial que el legislador procesal construye recurriendo a distintas "piezas"26. Lo hemos señalado en otros sitios, cada vez que visualizamos un exceso de entusiasmo a favor de la instalación de la oralidad. Y

maniqueos y con presupuestos axiomáticos absolutos. Según ese maniqueísmo, la oralidad es el bien y la escritura, el mal. Y, bien mirados, los presupuestos aludidos han sido y son en muchos lugares la moda y la ideología, ambas desnudas de justificación, ambas presentes como quien, muy pagado de si mismo, piensa que ha de ser protagonista exclusivo por méritos que considera notorios e indiscutibles... aunque, en el fondo, nadie conozca esos méritos ni haya tenido la oportunidad de discutirlos". DE LA OlIVA SANTOS, A. (2009). Casación, oralidady nuevo proceso civil (tres conferencias chilenas) (Santiago, Ediciones Jurídicas de Santiago), p. 63. De su parte, para Taruffo existen dos mitos asociados a la idea de la oralidad. El mito positivo: la oralidad como valor óptimo básico, una especie de panacea que debiera resolver todas las dificultades del funcionamiento del proceso civil. Y el mito negativo: la escritura es esencialmente perversa y responsable de la mayoría de los problemas que surgen en un litigio civil, por lo que debiera reducirse al mínimo, o bien anularse. Agrega, con total acierto: "No tengo nada contra los mitos en general: forman parte de cada cultura y, junto con las ideologias (y las más de las veces mezclados con éstas) proporcionan una base para cualquier tipo de construcciones sociales y jurídicas. Sin embargo, también pueden ser un obstáculo poderoso en el correcto entendimiento de los mecanismos procesales". TARuffo, M. (2009). "Oralidad y escritura como factores de eficiencia en el proceso civil", en: Páginas sobre Justicia civil (Madrid, Ed. Marcial Pons), p. 245.

${ }^{24}$ Bien lo apunta Alvarado Velloso. Véase: Alvarado Velloso, A. (2003). El debido proceso de la garantía constitucional (Rosario, Ed. Zeus), p. 266.

${ }^{25}$ Es lo que parece desprenderse de algunos escritos locales y extranjeros que sitúan al juicio oral como elemento central del debido proceso: Duce, M., Marín, F. y Riego, C. (2008), pp. 20-28; Duce, M. y Riego, C. (2007). Proceso penal (Santiago, Ed. Jurídica de Chile), pp. 375-385. Otros, como Carocca, han planteado la existencia de un verdadero derecho a un juicio civil regido por el "principio" de la oralidad: CArOcCA Pérez, A. (1997). Derechos Humanos y derecho Civil: Perspectiva procesal (Santiago, Centro de Desarrollo Jurídico Judicial, CPU, Serie Estudios), p. 70; LorCa NaVArRete, A. (2007). "La garantía de la oralidad en la exigencia de tutela judicial efectiva civil”, en Revista Vasca de Derecho Procesal y Arbitraje (Vol. 19, o 3), pp. 355-358.

26 "El proceso es pura invención humana, un artificio, un artefacto, que no funciona, o funciona mal, aunque su idea básica sea buena, si las piezas, grandes y pequeñas, no están bien construidas o no engranan debidamente y por supuesto, si nadie conoce suficientemente el artefacto, si sus operadores no leen o malinterpretan el manual de funcionamiento, porque no saben leer bien o-esto es lo más frecuente- porque el manual está escrito con oscuridad". Véase: Carreras Llansana, J. (1962). "El Derecho procesal como arte", en Carreras Llansana, J. y Fenech Navarro, M. Estudios de Derecho procesal (Barcelona, Ed. Bosch), pp. 51-62; De la Oliva Santos, A. y otros (2004). Derecho Procesal: Introducción, 3a edición (Madrid, Ed. Universitaria Ramón Areces), pp. 44-45; De la Oliva Santos, A. (1996), p. 16. 
no es que nos opongamos a ella (claramente no es así), sino que asumimos que su introducción en materia civil debe realizarse dentro de nuestras posibilidades, con razonabilidad y sentido de utilidad, sin desmedro ni retroceso para las garantías de los justiciables. Por ello, recordar que el proceso es una realidad artificial que no preexiste a su regulación por el legislador (sino que nace con ella), sirve para poner en evidencia la distinta naturaleza de las piezas a las cuales éste debe y puede echar mano, a fin de lograr que su producto final sea un instrumento que se acerque lo máximo posible a la justicia y a la eficacia en la solución jurisdiccional de los conflictos jurídicos.

En la labor de creación antedicha el legislador está obligado a recurrir a determinadas piezas y está facultado para utilizar otras. Las primeras son una imposición, las segundas una opción. No se trata, por tanto, de piezas que gocen de la misma importancia o que estén a la misma altura. Las piezas que vienen impuestas y que el legislador procesal no puede desatender en su labor de creación son aquellos principios (verdaderos principios) sin los cuales no puede siquiera hablarse verdaderamente de un proceso. Así, el proceso se deberá configurar por el legislador de modo que siempre sean efectivos y respetados determinados postulados elementales de justicia, de allí su carácter necesario ${ }^{27}$ e imprescindible ${ }^{28}$. Los principios de igualdad de las partes, de contradicción, de imparcialidad, de moralidad del debate son anotados por la mejor doctrina como postulados mínimos y fundamentales que deben estar presentes para hablar efectivamente de un proceso. Sin ellos el instrumento creado dejaría de ser cauce adecuado para la tutela de los derechos e intereses de los ciudadanos e instrumento lógico de la jurisdicción ${ }^{29}$.

Fuera de estas piezas que forzadamente deben estar presentes a la hora de configurar un proceso, lo que existe no son principios (por más que así se les denomine impropiamente $)^{30}$, sino simplemente reglas técnicas que están a disposición del

\footnotetext{
${ }^{27}$ De la Oliva Santos, A. et al. (2004), p. 56.

${ }^{28}$ Alvarado Velloso, A. (2003), p. 254. Se ha señalado al respecto: "Sólo mencionar la posibilidad de que un proceso consagre el principio de deslealtad, o de la parcialidad del juez o el de dilación del proceso o inexistencia de la cosa juzgada, repugna, con lo cual es evidente lo exclusivo y restrictivo de los verdaderos principios, una de cuyas notas salientes, se reitera, es no admitir contrarios... Todos los demás tradicionalmente ubicados y enseñados como tales, son reglas técnicas de procedimiento, llámense dispositivo, inquisitivo, mediación, inmediación, escritura, oralidad, única o dos instancias, publicidad y conciliación siendo menester sin desconocer su importancia, ubicarlos debidamente de conformidad con su alcance conceptual”. López Blanco, H. (1997). Instituciones de Derecho Procesal Civil Colombiano, $7^{\text {a }}$ edición (Bogotá, Dupre Editores, T. I, Parte General), pp. 50-51.

${ }^{29}$ Berzosa Francos, V. (1992). "Principios del proceso", en Revista Justicia (No 2), p. 560.

${ }^{30}$ Seguimos lo que señala Andrés de la Oliva: "No es acertado ni conveniente, desde ningún punto de vista, denominar principios a todos los criterios generales en virtud de los cuales se opta por regular de un modo
} 
legislador procesal para que éste pueda ajustar el instrumento que está creando a la finalidad de tutelar eficazmente y configurarlo externamente. Se trata de postulados que se presentan siempre como pares antinómicos ${ }^{31}$. Oralidad y escritura forman parte de este grupo de piezas, por lo que cuando se habla de la oralidad no se está haciendo mención de un verdadero "principio"32, sino que a algo que posee una importancia sensiblemente menor que la que ostentan aquéllos ${ }^{33}$. En este terreno no existen imperativos, existen las opciones y la posibilidad cierta de combinaciones de estas reglas como queda demostrado en las legislaciones procesales modernas que si bien introducen la regla de la oralidad con carácter predominante, no renuncian (por diversas razones) a que ciertos actos o fases del proceso sigan siendo configuradas desde la regla de la escritura ${ }^{34}$.

Resituada la idea de la oralidad en el plano que le corresponde (como regla y no principio procesal), e insistiendo que la opción por la oralidad no impone desechar la contribución de la regla de la escrituración, menester es recordar que su aportación viene dada fundamentalmente por facilitar al juez decidir con inmediación, concentración y publicidad real ${ }^{35}$. Son estos componentes los que permiten identificar un proceso predominantemente oral, distinguiéndolo de un proceso preferentemente escrito, como el que actualmente rige en nuestro país, en donde estas reglas asociadas a la oralidad tienen difícil o nula cabida.

Si tratándose de la oralidad existe la posibilidad de combinaciones con la escritura, esto también es predicable respecto de las reglas que se le asocian como configurando un sistema. Constituye una atribución del legislador apostar por el predominio de una u otra, y debe saber darles la mejor utilización posible de acuerdo a criterios de conveniencia y oportunidad, sin pretender llevarlas hasta

o de otro el proceso o ciertos aspectos o actuaciones de éste. Para esos criterios resulta preferible utilizar los conceptos y términos de reglas o máximas. Como he dicho en otros lugares y ocasiones, cuando todo son principios, nada es principio. Y lo mismo sucede cuando a cualquier posibilidad de actuación humana se le denomina derecho: cuando todo son derechos, nada es derecho. Semejante amplitud conceptual no conduce a nada positivo". De la Oliva Santos, A. et al. (2004), p. 56.

${ }^{31}$ Alvarado Velloso, A. (2003), p. 264.

${ }^{32}$ Montero Aroca, J. (2007), p. 255.

${ }^{33}$ Alvarado Velloso, A. (2003), p. 264.

${ }^{34}$ En este sentido, Ortells: "Es antigua la constatación de que ni los sistemas procedimentales vigentes, ni las pretensiones de reforma se orientan hacia el establecimiento en su estado puro de alguna de las formas citadas, sino que más bien reflejan y tienden a una combinación de formas orales y escritas. El problema de la oralidad y de la escritura en el procedimiento se plantea a menudo como un problema de predominio o de coordinación y no de exclusión total". ORTElLs Ramos, M. Formas del procedimiento y garantías fundamentales del proceso civil", inédito, se publicará en Boletín de la Academia de Ciencias Sociales de Venezuela.

${ }^{35}$ Bonet Navarro, J. (2009a), p. 62. 
las últimas consecuencias por mero respeto a una determinada concepción de la dogmática procesal.

\section{b) Doble sentido de la inmediación. El notable cambio que implica con la situación imperante en un modelo escrito}

La inmediación judicial efectiva es uno de los objetivos más caros que se busca conseguir tomando la opción hacia la oralidad en los procesos civiles ${ }^{36}$. Se entiende que a través de ella se puede lograr cambiar el rostro a una Justicia que se percibe lejana por los ciudadanos ${ }^{37}$, humanizando el proceso ${ }^{38}$ al permitir a las partes "ver la cara del juez" a quien han confiado la resolución del asunto ${ }^{39}$. En términos generales, se coincide en señalar que la inmediación impone que el juicio y la práctica de la prueba han de transcurrir ante la presencia del órgano jurisdiccional competente, sin posibilidad de delegación en terceros ${ }^{40}$. Así se ha dicho que un proceso está presidido por el "principio" de inmediación, cuando se impone una conexión directa del juzgador con los intervinientes del juicio y la realidad que ha de enjuiciar ${ }^{41}$. Pero más allá de esta general aproximación a la idea de la inmediación, se suele distinguir entre inmediación en sentido amplio e inmediación en sentido estricto.

La inmediación en sentido amplio responde a la descripción antes apuntada y se vincula fundamentalmente con la necesaria presencia judicial en la práctica de las pruebas, esto es, supone que el juez asista a la práctica de las pruebas y

\footnotetext{
${ }^{36}$ De Miguel y Alonso, C. (1975). "El principio de la inmediación dentro del sistema formal de la oralidad", en Boletín Mexicano de Derecho Comparado (Nueva Serie, Año VIII, No 24), pp. 791 y ss.

${ }^{37}$ Pereira Campos, S. "El principio de inmediación en el proceso por audiencias: mecanismos legales para garantizar su efectividad", Revista internauta de práctica jurídica, No 11, 2002, p. 2.

${ }^{38}$ Carús Guedes, J. (2003). O principio da oralidade (Sao Paulo, Ed. Revista Dos Tribunais), p. 62. En similar sentido se ha dicho que la idea que está detrás de la inmediación es que la cercanía con el drama humano encerrado en el proceso, le va a proporcionar al juez mayores o mejores elementos de convicción para expedir un fallo que se adecue a lo que realmente ocurrió, es decir, a la obtención de una decisión justa. Monroy Gálvez, J. (1996). Introducción al proceso civil (Santa Fe de Bogotá, Ed. Temis, Estudio de Belaunde \& Monroy Abogados), p. 94.

${ }^{39}$ Picó I JunOY, J. (2008); "El principio de oralidad en el proceso civil español”, en Carpi, F. y Ortells, M. (editores) Oralidad y escritura en un proceso civil eficiente (Valencia, Universidad de Valencia, Tomo I,), p. 363.

${ }^{40}$ Herrera Abián, R. (2006). La inmediación como garantía procesal (en el proceso civil y en el proceso penal) (Granada, ed. Comares), pp. 3-4.

${ }^{41}$ De las Heras García, M. (2002). "Consideraciones relativas al principio de inmediación en la LEC/2000", en Revista del Poder Judicial (No 6), p. 180.
} 
entre en relación directa con las partes, con los testigos, con los peritos y con los objetos del juicio ${ }^{42}$. Pero bien se ha precisado que con esto no es suficiente, y es aquí donde entra en escena la inmediación en sentido estricto. En efecto, si bien la inmediación comienza a desplegarse con la presencia física y sensorial del juez al producirse la prueba, supone además que sea también él quien pronuncie, en mérito de esa información, la sentencia ${ }^{43}$.

Así, mientras la inmediación en sentido amplio se contempla como un requisito de formalidad o de seriedad en el desarrollo de las actuaciones y en la práctica de las pruebas, la inmediación en sentido estricto (o verdadera inmediación según explica Montero Aroca) impone que el juez que ha presenciado la práctica de las pruebas sea quien dicte el fallo ${ }^{44}$, ya que justamente esa presencia efectiva en la práctica de las actuaciones probatorias sitúa al órgano judicial en las mejores condiciones de conocer el objeto del proceso ${ }^{45}$ : "la ausencia de intermediarios que puedan distorsionar, voluntaria o involuntariamente lo transmitido, aporta al órgano juzgador una posición óptima para ponderar todos los elementos y valorarlos correctamente, sobre todo si se tiene en cuenta el sistema probatorio de libre valoración de la prueba donde la inmediación juega un papel esencial al permitir la aplicación de las reglas de la sana crítica sin influencias de intermediarios" ${ }^{2 \% 6}$. De allí que se sostenga que la exigencia de inmediación stricto sensu va íntimamente ligada a la forma oral del proceso ${ }^{47}$.

Aunque la exigencia de presencia judicial en la práctica de las pruebas ya existe en la letra de la ley, lo cierto es que ambos sentidos de la inmediación son de difícil concreción efectiva en un modelo procesal escrito y desconcentrado ${ }^{48}$. Es un modelo que pone cortapisas prácticamente insalvables a la inmediación judi-

\footnotetext{
${ }^{42}$ Berzosa Francos, V. (1992), p. 613.

${ }^{43}$ Tavolari Oliveros, R. (2008). "La prueba entre la oralidad y la escritura”, en Carpi, F. y Ortells, M. (editores) Oralidad y escritura en un proceso civil eficiente (Valencia, Universidad de Valencia, Tomo I), p. 407.

${ }^{44}$ Montero Aroca, J. (2007), p. 277.

45 "Mientras más inmediata la percepción, mayor calidad de la misma”. Duce, M., Marín, F. y Riego, C. (2008), p. 32.

${ }^{46}$ Herrera Abián, R. (2006), p. 4.

${ }^{47}$ Vallines GarCía, E. (2006). "Sobre la posibilidad de revisar la valoración de las pruebas mediante el recurso de casación penal: estado de la cuestión a la luz del derecho del condenado a la revisión de su sentencia y del principio de inmediación", en Revista la Ley Penal (No 23), p. 14.

${ }^{48}$ Se ha dicho en su momento, muy ilustrativamente: inmediación y proceso civil: la búsqueda de un imposible. Villalaín Ruiz, E. (1993). "Inmediación procesal o presencia del juez en las actuaciones como el garante de la igualdad de partes", en Cuadernos de Derecho Judicial, Principios constitucionales en el proceso civil, CGPJ, p. 402.
} 
cial $^{49}$. Esta situación, que puede calificarse de estructural, debe entenderse como la causa fundamental del modelo de juez ausente e invisible hasta el momento de fallar que tenemos.

Efectivamente, el carácter escrito del procedimiento, su disgregación y su duración han ido justificando el fenómeno de la "desaparición" del juez durante el curso del mismo, salvo en lo que se relaciona con la dictación de las resoluciones. En esta dinámica formal se ha impuesto la intermediación y la delegación, incluso con el apoyo de expresas normas legales que así la autorizan, resintiendo de esta manera actividades tan centrales como la prueba. Se pierde confiabilidad y respeto por la administración de justicia ${ }^{50}$.

La forma escrita no se ha mostrado como una buena compañera cuando se trata de la actividad de la prueba, y no lo ha sido porque un proceso civil tan escrito como el que recoge el CPC chileno apunta en la dirección contraria a la que aparece como la más razonable, conveniente y útil tratándose de la actividad probatoria, la que exige un contacto directo y frontal del juez con las partes y sus distintos medios de prueba. En un sistema escrito que tiende a la desconcentración y dispersión de los actos, también de las actuaciones probatorias, la inmediación judicial en la práctica probatoria suele no tener un correlato efectivo con aquello que disponen las normas legales, existiendo un claro desaliento para el concurso efectivo de la presencia del juez en la actividad relativa a la práctica de las pruebas.

El modelo facilita la intermediación, con la consiguiente invisibilidad del juez. Bien se ha señalado, que debe existir en jueces de procesos escritos un sentimiento de inutilidad ${ }^{51}$ respecto a la inmediación, motivado por la dispersión y desconcentración existente a propósito de la práctica de pruebas, pero también por el prolongado y excesivo tiempo que transcurre desde esta práctica probatoria dispersa y la dictación de la sentencia. De hecho, por el diseño y los tiempos que impone

\footnotetext{
${ }^{49}$ Además, por mucho tiempo se consideró como pertinente y adecuada la mediación, es decir, se postuló que mantener al juez alejado de los protagonistas del conflicto y de todo aquello que constituyan elementos objetivos de éste, es lo que precisamente iba a permitir al juzgador la expedición de decisiones justas e imparciales. Véase: Monroy Gálvez, J. (1996), p. 94.

${ }^{50}$ Pereira Campos, S. (2006). "Una reforma exitosa: la reforma procesal civil en Uruguay” en Silva, José Pedro y otros (editores) (Santiago, Libertad y Desarrollo, P. Universidad Católica de Chile y Universidad Autónoma de Madrid), p. 766.

${ }^{51}$ Así se ha destacado que se trata de una consecuencia directa del predominio de la escritura, que hace surgir el convencimiento de la inutilidad o inoportunidad del contacto directo del juez con los elementos que componen la causa, pues todos sus resultados deberán ser consignados por terceros en actas y serán las únicas que deberán utilizarse para pronunciar la decisión. Véase: Prieto Castro, L. (1950). "Precisiones sobre la escritura y la oralidad en el Derecho procesal español", en Estudios y comentarios para la teoría y práctica procesal civil (Madrid, Ed. Reus), pp. 75 y ss. Al respecto puede verse también: CappelletTr, M. (1972), p. 36.
} 
la estructura escrita y desconcentrada de nuestro proceso ${ }^{52}$, resulta prácticamente imposible que los jueces puedan dictar la sentencia con el recuerdo cercano de la prueba rendida (suponiendo que haya efectivamente asistido a dicha práctica probatoria), quedando necesariamente constreñidos a recurrir a la constancia escrita de las actas. En fin, existe un modelo escrito con un juez presente sólo "al final del trayecto procesal" que se ve en la necesidad de recurrir a las actas que imposibilitan tomar conocimiento de las expresiones, tono de voz, gestos, firmeza y actitudes que acompañan la declaración de testigos o de las mismas partes, lo que la oralidad sí permitiría ${ }^{53}$ y aparece como uno de los aspectos positivos que se asocian a la idea de los procesos orales gracias a la inmediación judicial efectiva que imponen, regla que "permite al juez utilizar en la valoración de las pruebas la observación directa e inmediata ${ }^{34}$ tornando posible una mejor y más completa ilustración del decisor ${ }^{55}$ "con miras a lograr una decisión fiable y verdadera sobre los hechos"56.

\section{c) Introducción de una oralidad, concentración e inmediación judicial razonables, no hay necesidad alguna de recepcionarlas plena y radicalmente}

La apuesta por reforzar la regla de la oralidad es una apuesta que se ha destacado con un reforzamiento efectivo de la regla de la inmediación judicial y de la concentración procesal ${ }^{57}$. Pero reconocida y destacada esta asociación de reglas en torno a la oralidad, cabe no caer en la tentación de pretender que es posible y conveniente imponer diseños dogmáticos puros que, la experiencia comparada lo evidencia, no contribuyen a lograr un instrumento más útil, razonable, serio y realista. Conviene insistir, a riesgo de ser majaderos: estamos en frente de reglas y no de verdaderos principios, por tanto, es perfectamente posible que el legislador

\footnotetext{
${ }^{52}$ Se ha destacado por la doctrina que la inmediación es enemiga de la dilación. "Los resultados favorables de aquélla, las impresiones y recuerdos, se borran, desaparecen de la mente del Tribunal, en la medida en que el lapso del tiempo, que puede transcurrir entre la práctica y la valoración de la prueba, sea excesivamente dilatado. De aquí que resulte necesario pronunciar la sentencia también inmediatamente en el tiempo, acto seguido a la finalización del juicio oral". Cortés Domínguez, V., Gimeno Sendra, V., Moreno Catena, V. (2003). Derecho Procesal Civil. Parte General, 5a edición (Madrid, Ed. Colex), p. 41.

53 Pereira Campos, S. (2006), p. 767.

${ }^{54}$ Fairén Guillén, V. (1988). El Tribunal de Aguas de Valencia y su proceso: Oralidad, concentración, rapidez y economía, 2a edición (Valencia, Ed. Caja de Ahorros de Valencia), p. 505.

55 Simón, L. (2007). "La prueba entre la oralidad y la escritura", en Revista Uruguaya de Derecho Procesal (No 3), p. 613.

${ }^{56}$ Taruffo, M. (2008). La prueba (Madrid, Ed. Marcial Pons), p. 75.

${ }^{57}$ Palomo Vélez, D. (2009). "Las marcas del proceso oral y escrito diseñado en el Proyecto de nuevo CPC", en Revista Chilena de Derecho (Vol. 36, No 3), pp. 621-661.
} 
recoja y concrete combinaciones entre ellas ya que, tratándose de éstas, no está sujeto a imposiciones ${ }^{58}$.

En efecto, que la reforma procesal en curso tienda a introducir la oralidad a la Justicia civil ${ }^{59}$ no debe significar (como de hecho no significa en el Proyecto) descartar la escritura para todos los efectos ${ }^{60}$. Al contrario, la escritura puede seguir prestando utilidad para determinados actos del proceso, especialmente (no únicamente) los actos de alegación inicial de las partes, léanse la demanda, la contestación de la misma y la eventual reconvención. La oralidad debe imponerse teniendo a la vista un criterio que diga relación con la funcionalidad de cada etapa del proceso. Tratándose del carácter escrito de las alegaciones iniciales de las partes se está buscando facilitar la exposición ordenada de los hechos y de los fundamentos jurídicos. La forma escrita aparece como la más razonable, conveniente y segura de acuerdo al importante rol asignado primero a la demanda (como acto iniciador del proceso, como en la determinación y delimitación del contenido del mismo) y luego a la contestación y eventual reconvención. A pesar de que estos actos conservan su carácter escrito, nadie puede negar que el modelo procesal que se está proponiendo sea predominantemente oral cuando se revisan los contenidos e importancia que se asigna a las dos audiencias que siguen a estos actos iniciales escritos. Ya anotamos que en las legislaciones procesales modernas que optan por este modelo "de audiencias" buscan combinar adecuadamente la oralidad con la escritura ${ }^{61}$.

A su turno, la apuesta por dejar atrás la disgregación procesal propia de un sistema escrito y apostar por un modelo procesal concentrado no debe significar llevar la regla de la concentración hasta las últimas consecuencias. Si así se entendiere, un proceso oral impondría, entre otras medidas, la concentración en un solo acto de prácticamente todas las actuaciones del proceso, lo que desde luego aparejaría dañinas consecuencias de diversa naturaleza. De hecho, la experiencia comparada ha demostrado que al optarse por un diseño más oral y concentrado

\footnotetext{
${ }^{58}$ Buen ejemplo de que este ejercicio es posible es el caso de la reforma española. Véase: Palomo VéLEz, D. (2008). La oralidad en el proceso civil. El nuevo modelo español (Santiago, Ed. Librotecnia), p. 641.

59 (2007). “Informe”, p. 11.

60 "En un mismo sistema jurídico, en una misma jurisdicción y en un mismo proceso coexisten la oralidad y la escritura de tal manera que ninguno de ellos constituye una técnica absoluta, no son excluyentes, se complementan". OchoA Moreno, B. (2005). "La implementación de la oralidad en el proceso laboral: debate en torno a la congestión laboral”, en Diálogos de saberes: Investigaciones y Ciencias Sociales (No 23), p. 73.

${ }^{61}$ Pereira Campos, S. (2008). El proceso civil ordinario por audiencias: La experiencia uruguaya en la reforma procesal civil. Modelo teórico y relevamiento empirico (Montevideo, Ed. Amalio M. Fernández, CEJA), pp. 39 y ss.
} 
se presenta un importante problema, cual es, que debido a la ausencia de una fijación con carácter previo a la vista de las alegaciones y pretensiones de ambas partes, se termina en frecuentes suspensiones y aplazamientos ${ }^{62}$. Tampoco es nada aconsejable ni menos realista comenzar, bajo la excusa de imponerlo la oralidad y la concentración, a demonizar las autorizaciones para diferir por un plazo determinado la dictación de las sentencias ${ }^{63}$. El riesgo de caer en superficialidad y precipitación ya se ha puesto de relieve por algunos ${ }^{64}$. Conviene recordar acá lo señalado por De la Oliva: "Se ha dicho muy acertadamente que no se puede construir los procesos en abstracto, en la ley, como si se pensase que cada juez y cada abogado tienen sólo uno... El diseño más simple de un proceso oral puede verse contrarrestado con largas listas de espera para la celebración de los juicios o con una baja calidad de los pronunciamientos jurisdiccionales, en especial si en el ámbito de la magistratura se asocia inconscientemente la oralidad con una pretendida capacidad para dictar sentencias acertadas sin necesidad de un estudio detenido y atento de cada caso. $Y$ entre la lentitud y la justicia del cadi, parece preferible la primera, salvo que sólo se atienda a las estadisticas' 65 .

La misma moderación y ausencia de radicalidad que postulamos para la implementación de la oralidad y de la concentración, queremos sostenerla en relación con la regla de la inmediación. No vemos razones para dejar a un lado estos criterios para buscar consagrar la inmediación a ultranza. De hecho, en países que han reformado su legislación procesal civil consagrando un modelo predominantemente oral (como es el caso de España, LEC 1/2000) la regla de la inmediación no se lleva a extremos, de allí que, por ejemplo, se admita la práctica de pruebas por auxilio judicial cuando por razón de la distancia, por la dificultad de desplazamiento o por las circunstancias personales de la parte, del testigo o del perito o por cualquier otra causa de análogas características resulte imposible o muy gravosa la comparecencia en la sede del tribunal ${ }^{66}$. Se dio cuenta el legislador español que existen también otros intereses dignos de ser tenidos en

\footnotetext{
${ }^{62}$ En lo relativo a los problemas evidenciados por el diseño más concentrado del juicio verbal en España, véase: GASCÓN INCHAUSTI, F. (2008). "Un nuevo instrumento para la tutela de los consumidores y de los créditos transfronterizos: el proceso europeo de escasa cuantía”, en Revista Ius et Praxis (Año 14, No 1), p. 185.

${ }^{63}$ Es la sensación que queda tras la lectura de algunos textos. Véase: Duce, M., Marín, F. y Riego, C. (2008), p. 45.

${ }^{64}$ Nieva Fenoll, J. (2007b), pp. 43-44.

${ }^{65}$ De la Oliva Santos, A. (2004), p. 56.

${ }^{66}$ Véase: Montero Aroca, J. (2007), p. 278.
} 
cuenta $^{67}$. Tratándose de la doble instancia y la apelación de las sentencias definitivas, no cuesta imaginar que el interés del litigante es contar con una garantía de revisión de los hechos y del derecho, realizada por jueces de experiencia ${ }^{68}$.

\section{d) Mayor relevancia de la prueba documental en los procesos civiles}

Cuando se trata de analizar una cuestión que aparece para muchos como muy problemática (relación entre la oralidad, la apelación y la segunda instancia), conviene no caer en la lógica de seguir aportando complejidad al supuesto problema, planteándolo como si se tratara de algo sin solución, sino que lo que corresponde es contribuir a despejar el análisis de factores o elementos que pueden estar distorsionando la mejor y más razonable respuesta. Algo de esto sucede cuando nos ponemos a pensar en la relación existente entre, primero, la prueba documental y los procesos civiles, y segundo, la oralidad y la prueba documental.

En efecto, en lo que dice relación con la prueba documental en los procesos civiles cabe recordar que este medio de prueba ha sido y sigue siendo considerado en la teoría y en la práctica forense como la reina de las pruebas en materia procesal civil. Guasp, buscando diferenciar la realidad probatoria en materia civil y penal, afirmó no sin razón que "el proceso civil es el reino del documento, mientras que el proceso penal es el reino del testigo" ${ }^{69}$. Y es que es una realidad difícil de refutar que en la mayoría de los procesos civiles gran parte de los elementos de convicción son de carácter documental ${ }^{70}$.

Esta simple constatación sirve (y bastante) para poner la discusión en sus justos términos, sin desbordes ni excesos, evitando trasplantar los debates producidos en materia procesal penal a la reforma procesal civil en circunstancias que estamos frente a realidades bien diferentes, en donde el eje de las pruebas viene dado por la testimonial en el primer caso, y por los documentos, en el se-

${ }^{67}$ En todo caso, bien se apunta, que las excepciones legales que se contemplan, lo son a la inmediación en sentido estricto y no a la presencia judicial o inmediación en sentido amplio, la que en caso alguno puede admitir excepciones: Herrera Abiân, R. (2006), p. 37.

${ }^{68}$ Langbein, J. (2002). "La ventaja alemana en el proceso civil", en Revista Iberoamericana de Derecho Procesal (No 9, Año VI), pp. 145-148.

${ }^{69}$ GuAsP, J. (1996). La prueba en el proceso civil español: Principios fundamentales (Madrid, Estudio Jurídico Madrid), p. 415. En similar sentido Herrera Abián: "La prueba testifical sigue siendo la prueba reina en el proceso penal; es la que con más frecuencia se practica en el procedimiento para conformar la convicción judicial sobre los hechos que constituyen su objeto, y es, sin duda alguna, la prueba en que la inmediación adquiere importancia mayor". Herrera Abí́n, R. (2006), p. 95.

${ }^{70}$ Muñiz Calaf, B. (2002). La segunda instancia en la nueva Ley de Enjuiciamiento Civil (Madrid, Ed. Dykinson), p. 18. 
gundo, según hemos señalado. Es que la situación de ambos medios de prueba es bien distinta de cara a un contexto de juicio oral. Así se dice que mientras los medios probatorios documentales (medios de prueba no personales en general, por ejemplo, los nuevos medios de reproducción del sonido o la imagen) no requieren actuación y la situación del juez de primera instancia respecto a este material es la misma que pueda tener el tribunal de segunda instancia ${ }^{71}$, no ocurre lo mismo con las pruebas personales (u orales, como también se las denomina ${ }^{72}$ ) que sí requieren de actuación y en donde la mayor o menor credibilidad que pueda asignar a los testimonios están en relación con la situación del juez de primera instancia.

Bien decía Cappelletti ${ }^{73}$ que la importancia de la prueba documental no tiene por qué disminuir y de hecho no disminuye por optarse por un modelo procesal oral, al menos en aquellos ordenamientos procesales que han sabido realizar con éxito esta reforma hacia la oralidad. Por lo tanto, si bien la apuesta hacia la oralidad y sus reglas conexas significan una revalorización importante de las pruebas personales ${ }^{74}$, esa revaloración no se acompaña de lo que sería una irracional desvalorización de la prueba documental o preconstituida, "la cual, aun antes que en el proceso, opera benéficamente fuera del proceso, en el mundo de las relaciones sustanciales, creando un cierto grado de certeza y de confianza de los coasociados en sus negociaciones y en general en sus relaciones jurídicas"

Son estas dos constataciones, la mayor importancia de la prueba documental en el proceso civil y la mantención de su relevancia en los procesos orales, las que deben permitir comenzar a reconducir a su real dimensión las denuncias de incompatibilidad entre un modelo procesal oral y el sistema de doble instancia. Desde esta perspectiva, coincidimos con algunos autores, el eventual problema de incompatibilidad pierde bastante en relevancia ${ }^{76}$.

\footnotetext{
${ }^{71}$ Calderón Cuadrado, M. Pía. (2004). "El proceso civil y su estructuración en dos instancias. Problemática que plantea, en Libro homenaje al profesor Dr. D. Eduardo Font Serra (Madrid, Ministerio de Justicia: Centro de Estudios Jurídicos, T. I), p. 835.

${ }^{72}$ Comoglio, L., Ferri, C., TAruffo, M. (2005). Lezioni sul processo civile. I. Il processo ordinario di cognizione,

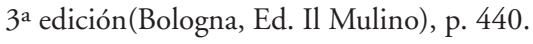

${ }^{73}$ Cappelletti, M. (1972), p. 89.

${ }^{74}$ Palomo Vélez, D. (2007). "La prueba en el proceso civil chileno: ¿¿Una actividad asumida con suficiente seriedad?, en De la Oliva Santos, A. y Palomo Vélez, D. (coordinadores) Proceso civil: Hacia una nueva Justicia civil (Santiago, Ed. Jurídica de Chile), pp. 360-363.

${ }^{75}$ En este mismo sentido, véase: TARUfFo, M. (2008), p. 75.

${ }^{76}$ Muñiz Calaf, B. (2002), p. 18.
} 


\section{e) La inmediación idealizada: no todo son fortalezas}

Unido a lo anterior, y en este afán de ir despejando el análisis de este problema, esquivando la idealización de las reglas asociadas a la oralidad, en este caso la inmediación, conviene tomar nota de algunas observaciones que se han venido formulando, si bien para los procesos penales, aplicables también para la situación de los procesos civiles, en relación con la real contribución que cabe esperar de la inmediación del juzgador ${ }^{77}$. Como hemos anotado, existe un amplio consenso en la doctrina para reconocer en los modelos procesales orales (con inmediación y concentración) una fórmula que asegura una verdad procesal de superior calidad, justamente facilitada por la concentración de las actuaciones probatorias y, especialmente, por el contacto directo del tribunal con las fuentes de ésta, en particular las de carácter personal ${ }^{78}$ como la testimonial $^{79}$. En este sentido, se destaca la importancia del juicio presencial que ofrece la ventaja de que en la viva voz hablan también el rostro, los ojos, el movimiento, el tono de voz, los silencios y otras actitudes que acompañan a la palabra y que también forman parte del mensaje transmitido, garantizando, al menos como regla, un mayor acierto en la valoración del testimonio ${ }^{80}$.

Pues bien, en esta idealización de la contribución que ofrece la inmediación se ha incurrido en algunos vicios, errores y excesos que conviene advertir. En aquellos sistemas que recogen la oralidad e inmediación judicial comienza a reproducirse el argumento de que no resulta posible revisar la valoración de la prueba llevada a cabo por el tribunal de la instancia ${ }^{81}$, porque el que conoce a través del recurso "no ha oído con sus oídos ni visto con sus ojos la prueba testifical". "La oralidad, la

\footnotetext{
${ }^{77}$ Las observaciones de advertencia para evitar excesos sirven también en el orden jurisdiccional civil, pero cabe tener presente que en el proceso civil éstos son aún menos justificables. En efecto, en el orden jurisdiccional penal, al estar involucrada la garantía de presunción de inocencia (que no opera en sede civil), puede haber más problemas de encuadre con la segunda instancia, especialmente cuando el tribunal superior revoca una sentencia absolutoria en una segunda instancia en la que no existe, para el juicio sobre el elemento fáctico, las condiciones/garantías que sí se dan en la primera instancia: De la Oliva SANTOS, A. (1997), p. 979. Por eso la doctrina más entusiasta con la instancia única en materia penal no duda en señalar que todas estas "perplejidades" desaparecerían si la segunda instancia se abriera exclusivamente a favor del reo: VEGAS Torres, J. (1993). Presunción de inocencia y prueba en el proceso penal (Madrid, Ed. La Ley, Grupo Wolters Kluwer), p. 192.

${ }^{78}$ Así lo destaca uno de los autores que ha planteado críticas a esta visión en torno a la oralidad y la inmediación: ANDRÉs IbáNEZZ, P. (2003). "Sobre el valor de la inmediación (Una aproximación crítica)", en Revista Jueces para la Democracia (No 46), p. 57.

${ }^{79}$ Herrera Abián, R. (2006), p. 95.

${ }^{80}$ Herrera Abián, R. (2006), p. 95.

${ }^{81}$ Bonet Navarro, J. (2009a), p. 258.
} 
publicidad, la contradicción y sobre todo la inmediación representan las ventajas del proceso celebrado a presencia de los jueces que ven y oyen lo que ya después otros ojos

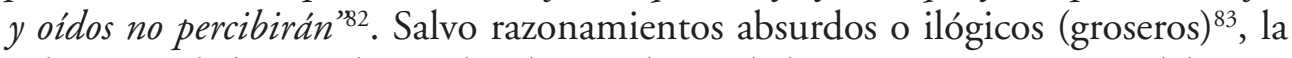
valoración de las pruebas realizada por el juez de la primera instancia se debe respetar impidiéndose una nueva valoración del material probatorio por el tribunal superior, que se autolimita ${ }^{84-85}$.

Se remata diciendo (siempre aludiendo a la segunda instancia del proceso penal y vinculando la cuestión con el tema de la presunción de inocencia): "Supone un elemento notablemente perturbador en el seno de dicho sistema (...) nada se gana, a nuestro juicio, y, por el contrario mucho se puede perder en cuanto a garantías se refiere, permitiendo la sustitución del convencimiento del juzgador de primera instancia, fundamentado en la prueba practicada en su presencia, por el convencimiento del órgano de apelación, fundamentado en una actividad probatoria que no ha presenciado" 86 .

Se centra todo en un problema de credibilidad o fiabilidad, según el cual la inmediación existente en la recepción probatoria se convierte, bien se ha dicho, en una suerte de blindaje del juicio, esquivándose una motivación más consistente y exhaustiva que dé efectivamente cuenta de la racionalidad de la decisión adoptada ${ }^{87}$ y consagrándose una noción subjetivista de la prueba, que termina vinculándola con la creencia del tribunal, desconociendo las exigencias propias de un sistema de valoración de la prueba libre, conforme a las reglas de la sana crítica ${ }^{88-89}$, derivando

\footnotetext{
${ }^{82}$ Así se destaca, críticamente, por algunos autores: Andrés Ibáñez, P. (2003), p. 58; Del Río Ferretti, C. (2002). "Consideraciones básicas sobre el sistema de prueba en materia penal y control sobre el núcleo fáctico mediante recurso de nulidad (y II)”, en Revista Internauta de Práctica Jurídica (No 9), p. 3.

${ }^{83}$ Como nos explica ilustrativamente Ortells, casi no es un tema de valoración de prueba, ¡es que se lo ha inventado!

${ }^{84}$ Herrera Abí́n, R. (2006), p. 185.

${ }^{85}$ Que esta autolimitación responda a un "respeto" por el modelo oral y sus reglas asociadas (inmediación) o a que los jueces de tribunales superiores se ven sobrepasados por el trabajo es otro tema, que en este trabajo no pretendemos dilucidar.
}

${ }^{86}$ Vegas Torres, J. (1993), p. 192.

${ }^{87}$ Taruffo habla de la motivación como garantía de racionalidad y de controlabilidad de las pruebas, haciendo posible un juicio posterior sobre las elecciones del juez en materia de valoración probatoria. TARUFFo, M. (2002). La prueba de los hechos (Madrid, Ed. Trotta), pp. 435-438; TARuffo, M. (2009), pp. 527 y ss.

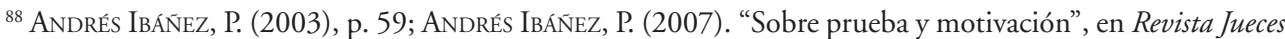
para la Democracia (No 59), pp. 80 y ss. Véase también: Accatino Scagliotti, D. (2006). "La fundamentación de la declaración de hechos probados en el nuevo proceso penal. Un diagnóstico", en Revista de Derecho, Universidad Austral de Chile (Vol. XIX, No 2), pp. 9-26.

${ }^{89}$ Debe reiterarse que establecer la valoración libre de la prueba no implica que dicha valoración sea arbitraria, caprichosa o irracional. Las reglas de la sana crítica se alzan como el camino a seguir en la valoración de las 
así la libertad en una valoración irracional ${ }^{90}$, en arbitrariedad ${ }^{91}$, en sacrificio de la motivación del denominado "juicio de hecho" y en una renuencia de los tribunales superiores a revisar la valoración probatoria, incluso tratándose del recurso de apelación (como viene ocurriendo en España), desnaturalizando el instituto al despojarlo de contenidos que le son propios ${ }^{92}$. De algún modo se estaría operando con la lógica de que los procedimientos procesales de conocimiento de los hechos proporcionarían resultados infalibles, que los jueces serían infalibles ${ }^{93}$.

Se olvida, primero, que aunque mucho hay que reconocer de positivo al contacto directo del juez con las fuentes de prueba (muy distinto a lo que ocurre en los procesos escritos), los jueces no son especialistas o expertos en psicología y que la lectura del lenguaje gestual no siempre será tarea pacífica, sino que está abierta a variadas interpretaciones susceptible de errores ${ }^{94}$, menos cuando éstos,

pruebas rendidas, que deben servir para su crítica o depuración. Se trata de normas empíricas sostenidas en la razón, la madurez, el buen sentido lógico y el sano juicio. Se trata, en definitiva, de una valoración razonada, motivada y responsable. Si bien el juez se hace con un mayor protagonismo, no puede ni debe entenderse como una especie de patente de corso para despegarse de las exigencias propias de una resolución debidamente razonada y motivada. Palomo Vélez, D. (2008), pp. 566-567. En similar dirección se ha señalado: “...la libre valoración de la prueba es libre sólo en el sentido de que no está sujeta a normas jurídicas que predeterminen el resultado de esa valoración. La operación consistente en juzgar el apoyo empírico que un conjunto de elementos de juicio aportan a una hipótesis está sujeta a los criterios generales de la lógica y de la racionalidad”. Ferrer Beltrán, J. (2007). La valoración racional de la prueba (Madrid, Ed. Marcial Pons), p. 45. Véase también: Taruffo, M. (2009). "Considerazioni sulle massime d’esperienza”, en Revista Trimestrale di Diritto e Procedura civile (Vol. 63, No 2), pp. 551-570; Ortells Ramos, M. (2009). Derecho Procesal Civil, 9a edición (Pamplona, Ed. Aranzadi), p. 370.

${ }^{90}$ Comoglio, L., Ferri, C., Taruffo, M. (2005), pp. 434-435.

${ }^{91}$ Ferrer Beltrán, J. (2003). "Derecho a la prueba y racionalidad de las decisiones judiciales", en Revista Jueces para la Democracia (No 47), p. 31; Gimeno Sendra, V. (2008), "La inmediación en la 2a instancia y las sentencias arbitrarias de la primera", en La Ley (No 6876), p. 2.

${ }^{2}$ Sin perjuicio que más adelante retomamos este punto más detenidamente, véase: BonET NAVARRo, J. (2009a), pp. 258-259; Picó I JunOY, J. (2009). "Valoración de la prueba y segunda instancia civil: Hacia la búsqueda del necesario equilibrio", en Revista Jurídica de Catalunya (No 3), pp. 55 y ss.; CALDERÓN CUADRADO, M. Pía, (2002). "Sobre la exigencia de inmediación en la nueva LEC y su compatibilidad con los recursos ordinarios", en Revista de Derecho, Universidad de Valencia (No 1), pp. 8 y ss.; Calderón Cuadrado, M. Pía. (2004), pp. 834 y ss.; Pérez Asenjo, A. (2008). "La valoración de la prueba en segunda instancia”, en Picó I Junoy, J. y Lluch, X. (Directores) Aspectos problemáticos en la valoración de la prueba civil (Barcelona, Ed. Bosch), pp. 153 y ss.

${ }^{93}$ Gascón Abellán, M. (2004). Los hechos en el derecho, 2a edición (Madrid, Ed. Marcial Pons), p. 42.

94 “...la palidez del rostro, el tartamudeo y la inseguridad en la expresión o lo que se haga con las manos durante el interrogatorio, a ojos de un observador no especializado en esa clase de exámenes y sin otros datos y antecedentes del declarante que los formalizados que consten en la causa, lo mismo podría significar miedo del culpable a ser descubierto en la escenificación de la mentira, que pavor del inocente a no ser creído en la afirmación de la verdad". "Las aportaciones testificales, aun cuando procedan de quien actúa con el firme propósito de ser fiel transmisor de lo percibido, pueden experimentar sensibles desviaciones de la realidad". 
en muchos casos, no cuentan con calidad y experiencia suficiente ${ }^{95}$. Pero además, aun reconociéndose una mejor posición del juez para decidir la credibilidad o fiabilidad de determinada fuente de prueba (gracias a la inmediación), debe puntualizarse, como bien lo ha explicado Del Río Ferretti entre nosotros, que la inmediación que efectivamente es la regla de mayor peso a la hora de la apreciación de la prueba y de la formación del convencimiento, no debe ser elevada necesariamente a un absoluto ${ }^{96}$. Así las cosas, "de la prueba hay cosas que necesariamente se tienen que apreciar directamente y hay otras que no necesitan ser apreciadas de esa manera" ${ }^{97}$. La inmediación hace posible en la apreciación de la prueba, formarse un juicio insustituible sobre la credibilidad de la prueba, mediante el examen directo de la prueba, para creer o no en ella. En otras palabras, la inmediación es la manera por la cual el tribunal realiza un acto de fe razonada en determinados medios de prueba que estima creíbles por sobre otros ${ }^{98}$. Pero, si

Andrés Ibáñez, P. (2003), pp. 60 y 65. Véase también: Gorphe, F. (2003). La crítica del testimonio (Madrid, Ed. Reus), 329 p.

${ }^{95}$ No es extraño escuchar las críticas que se formulan a la Academia Judicial, institución encargada de la selección, formación y perfeccionamiento de los jueces, por los parámetros que utiliza para seleccionarlos y formarlos. Se cuestiona que no se privilegie la experiencia profesional de los postulantes y se sobrevaloren las notas del pregrado, además de criticarse por insuficiente y general la formación que se entrega. Estas críticas, aunque no se lo propongan, vuelven a recordar que la oralidad no es para cualquier juez, sino que para jueces bien preparados y con experiencia, más aún cuando se trata de la reforma de la Justicia civil. Como bien lo ha apuntado Berizonce refiriéndose a la situación argentina, las reformas, sobre todo cuando son profundas, no se agotan en el dictado de una Ley, requieren de operadores preparados y capacitados, de excelencia. Nos preguntamos, a la luz de lo que la realidad muestra: ¿Existen suficientes garantías al respecto?. Bien se ha señalado que la idea de una instancia única ante un solo juez con un recurso extraordinario parece muy seductora en la teoría, pero la cuestión es si el país está listo para ella, más que por un tema de corte técnico, por la calidad que muestran los jueces. Véase: BERIZONCE, R. (2004). "La oralidad no es para jueces cómodos, sino al revés”, en Revista Sistemas Judiciales (CEJA, No 7), pp. 8 y ss.

${ }^{96}$ Del Río Ferretti, C. (2002), p. 5.

${ }^{97}$ Del Río Ferretti, C. (2002), p. 5.

98 "Por ejemplo, un testigo le parece más digno de ser creído en lo que ha dicho que otro que, sin embargo, en síntesis ha dicho más o menos lo mismo, no obstante, por razones de percepción inmediata de su relato se ha preferido uno y no otro. Tal vez, el primero fue más categórico y parecía más seguro. Tal vez se expresó en términos más comunes y corrientes y más propios de su condición social, lo que indujo al tribunal a pensar que su testimonio era más fidedigno, originario y menos posible de preparación. Tal vez soportó con mayor grado de aplomo, racionalidad (dio explicaciones más convincentes) y seguridad el contraexamen del abogado de la contraparte, y otras razones por el estilo que nos podamos imaginar. Todas estas razones para creer en unas pruebas y no creer en otras, sin duda sólo son susceptibles de ser apreciadas directamente por la persona que las evalúa, la posibilidad de advertirlas o apreciarlas mediatizadas por un escrito, produciría una baja considerable en la calidad de la información para pronunciar el juicio de valoración, porque se haría muy difícil o en algunos casos imposible, valorar una infinidad de detalles que se escapan del papel o que en él pierden toda su potencia insinuadora”. Del Río Ferretti, C. (2002), p. 6. 
no se cae en excesos, para apreciar la verosimilitud del relato o la contundencia de la prueba indirecta o indiciaria (o documental, como ya dijimos antes) no se requiere de inmediación ${ }^{99}$. Como bien se ha explicado, la verosimilitud es un problema que se presenta después del problema de la credibilidad ${ }^{100}$, toda vez que una vez que el juez ha optado por ciertos medios de los cuales se extrae una determinada versión de los hechos, de lo que se trata es de controlar la plausibilidad del relato, de apreciar si el relato que emana de la libre selección del material probatorio es objetivable ${ }^{101}$.

\section{LA DOBLE INSTANCIA Y SUS IMPLICANCIAS}

\section{a) La doble instancia, el recurso de apelación y la posibilidad de impugnación del juicio de hecho}

Según explicaba Couture, instancia es la denominación que se da a cada una de las etapas o grados del proceso, y que va desde la promoción del juicio hasta la primera sentencia definitiva, o desde la interposición del recurso de apelación hasta la sentencia que sobre él se dicte ${ }^{102}$. De allí que se hable de sentencia de única, primera o de segunda instancia, en donde presentándose la alternativa también se habla de regla procesal y no de principio, sin perjuicio de lo que más adelante se dirá en cuanto a la compleja conjugación de la instancia única con lo dispuesto en Pactos Internacionales que nuestro país ha suscrito y están vigentes con rango constitucional ${ }^{103}$.

Apelación y segunda instancia están, como bien se sabe, estrechamente relacionadas, implicando siempre el sistema de doble instancia la posibilidad de que el tribunal de categoría superior confirme o revoque y sustituya, total o parcialmente, la resolución que puso fin a la primera instancia que resulta impugnada por la

\footnotetext{
${ }^{99}$ Del Río Ferretti, C. (2002), pp. 6-7.

${ }^{100}$ Que es sólo el primer paso para establecer la conexión entre pruebas y hechos. TARUfFO, M. (2008), p. 139; Marinoni, L., CruZ Arenhart, S. (2008). Processo de conhecimento, $7^{\mathrm{a}}$ edición revisada y actualizada (Sao Paulo, Ed. Revista Dos Tribunais), p. 481. Según la explicación mantenida por Montero, que sigue a Calamandrei en este punto, se trata en rigor del segundo paso, dado que antes del problema de la verosimilitud y de la credibilidad estaría el problema de la interpretación, cuestión distinta a la de la valoración de la prueba en sentido estricto: Montero Aroca, J. (2002). La prueba en el proceso civil, $3^{a}$ edición (Madrid, Ed. Civitas), pp. 417-420.

${ }^{101}$ Del Río Ferretti, C. (2002), p. 7.

102 Couture, E. (2002). Fundamentos del Derecho Procesal Civil, 4a edición (Buenos Aires, Ed. B de F), p. 139.

${ }^{103}$ Alvarado Velloso, A. (2003), p. 284.
} 
apelación ${ }^{104}$, recurso devolutivo ordinario típico ${ }^{105}$, lo que viene a significar que devuelve al tribunal ad quem el conocimiento de la causa sin restringir el ámbito de la impugnación, permitiendo revisar cualquier aspecto de la resolución impugnada, bien se trate de un aspecto perteneciente al juicio fáctico o jurídico, sin que existan motivos taxativamente determinados en la ley. En efecto, en oposición al recurso de casación, recurso extraordinario típico, al que se le atribuye la función de vigilancia en el cumplimiento de la ley, el recurso de apelación permite una nueva cognición del litigio garantizándose la correcta aplicación del derecho y la justa impartición de justicia ${ }^{106}$.

Permite, por lo tanto, revisar lo resuelto en primera instancia. Con todo, como mantiene De la Oliva, aunque la segunda instancia comprende y supone evidentemente posibles actos de revisión de lo resuelto en primera instancia, su finalidad no es ni exclusiva ni primordialmente revisora. No se busca sobre todo comprobar si se han cometido errores jurídicos o en el juicio de hecho, sino ofrecer una nueva respuesta a unas concretas pretensiones de tutela jurisdiccional ${ }^{107}$. "La detección de esos errores está en función de la finalidad de respuesta a pretensiones de tutela. Si en la idea institucional de la segunda instancia dominara o predominara la revisión de la primera, a los sujetos jurídicos desencadenantes de la segunda instancia habría de exigírseles, ante todo y sobre todo, la denuncia fundamentada de los pretendidos errores y la consecuencia lógica rigurosa debiera ser el predominio en segunda instancia de lo que ha dado en llamarse jurisdicción negativa, de anulación parcial o total, en su caso, de lo erróneo" ${ }^{108}$.

\section{b) Ventajas y problemas de la supresión de la doble instancia. Transparentando las perspectivas que están detrás de las propuestas}

La cuestión de la supresión de la doble instancia ha captado desde hace años la atención de los reformadores ${ }^{109}$, especialmente cuando se trata de propuestas de reforma que buscan introducir la oralidad en los procesos. Se asume de entrada, con más dogmatismo que realismo, que la única alternativa que respeta el diseño y esencia de un modelo procesal oral y con inmediación judicial es la supresión

\footnotetext{
${ }^{104}$ De la Oliva Santos, A. et al. (2004), p. 489.

${ }^{105}$ Calderón Cuadrado, M. Pía. (1996). "Breves consideraciones sobre el recurso de apelación y el criterio de doble grado de jurisdicción”, en Revista de Derecho Procesal (No 3), pp. 560-568.

${ }^{106}$ GonZÁlez, M. (1998). La segunda instancia en el proceso civil (Barcelona, Ed. Cedecs), p. 27.

${ }^{107}$ De la Oliva Santos, A. et al. (2004), p. 490.

${ }^{108}$ De la Oliva Santos, A. et al. (2004), p. 490.

${ }^{109}$ Couture, E. (2002), p. 140.
} 
de la doble instancia ${ }^{110}$, dejando a un lado una serie de factores que también cabe tener presente a la hora de tomar tan crucial decisión. Pareciera que importara más ajustarse a lo que se entiende la más pura técnica procesal que atender a estos elementos, que bien vistos deben servir a la hora de tomar una decisión correcta.

La tesis de restringir el sistema recursivo (de eso se trata en definitiva), suprimiendo la doble instancia a través de la eliminación del recurso de apelación contra la sentencia definitiva, se sustenta por sus adherentes fundamentalmente en la necesidad de favorecer una respuesta más rápida y sencilla que alivie la carga de trabajo de la Justicia. Brevedad, simplicidad y economía son, por lo tanto, las ventajas que se suelen asociar a esta propuesta ${ }^{111}$. La necesidad de garantizar la imparcialidad en la administración de justicia y la necesaria uniformidad de la jurisprudencia se considera que pueden quedar satisfechas mediante los recursos extraordinarios que prevén la impugnación tasada de aquellas sentencias que se consideren afectadas de determinados vicios ${ }^{112}$.

Pero la anterior es sólo una de las perspectivas que puede utilizarse para afrontar este importante asunto. Es un modelo procesal pensado desde la perspectiva del Estado que, sin embargo, deja al margen o posterga la perspectiva de las partes. Vuelve a tener sentido preguntarse si se quiere construir un nuevo proceso desde el punto de vista del litigante que pide justicia, o bien se busca prescindir de esta perspectiva reemplazándola por la del Estado y sus órganos, en este caso, judiciales $^{113}$. Añadidamente, vuelve a salir a escena el debate, renovado en el último tiempo, entre los defensores del publicismo y del garantismo procesal ${ }^{114}$. En efecto, pretender que razones de economía son suficientes para abordar una reforma

${ }^{110} \mathrm{O}$ derechamente su desnaturalización, proponiéndose que el segundo grado de jurisdicción se limite a la questio iuris, sin poder extenderse a la questio facti. Véase: DE Souza LaSPro, O. (1993) "Oralidade e duplo grau de jurisdicao", en AA.VV. Scritti in onore di Elio Fazzalari (Milano, Ed. Giuffrè, Vol. II, Diritto Processuale Generale), p. 248.

${ }^{111}$ Beceña, F. (1933). "Sobre la instancia única o doble en el proceso civil", en Revista de Derecho Privado (No 234), p. 66.

112 Véase: GonZALlez, M. (1998), p. 33.

${ }^{113}$ Véase: CipRIANI, F. (2003). "El proceso civil italiano entre eficiencia y garantías", en Batallas por la Justicia civil (Lima, Ed. Cultural Cuzco, Compilación y traducción de Eugenia Ariano Deho), p. 167. Se ha dicho que uno de los aspectos de un sistema procesal que revela su inspiración garantista o autoritaria está en el sistema de impugnaciones previsto, pues ellas son el mecanismo que permite a las partes "defenderse" del siempre posible arbitrio judicial: Ariano Deho, E. (2003). "En defensa del derecho de impugnar en el proceso civil (vicisitudes de una garantía incomprendida”, en Ariano Deho, E. Problemas del Proceso civil (Lima, Ed. Jurista), p. 230.

${ }^{114}$ Para una visión general del debate, véase: Montero ArocA, J. (Editor) (2006): Proceso civil e ideologías: Un prefacio, una sentencia, dos cartas y quince ensayos (Valencia, Ed. Tirant lo Blanch), 440 pp. 
restrictiva del sistema recursivo sustentado en la doble instancia es prescindir en el análisis de elementos que deben ser necesariamente convocados y considerados si lo que se quiere es concretar una reforma realmente en beneficio de las personas. Expresivamente se ha sentenciado: "Problemas de esta especie no se resuelven sólo con el calendario" 115 .

Uno de estos elementos deriva de la concepción que se tenga de los recursos. Es claro que si éstos se entienden más como un mecanismo de control jerárquico y no tanto como garantías de los justiciables contra la arbitrariedad y errores que puedan cometer los tribunales en su actividad de sentenciar ${ }^{116}$, resulta bastante más llano el camino a reformas que pretendan suprimir la doble instancia ${ }^{117}$, que comienza a plantearse como prescindible. En cambio, si el planteamiento es del recurso de apelación y la doble instancia como garantía del justiciable, una reforma en la dirección indicada se convierte rápidamente en una reformatio in peius que conculca la garantía al doble examen del mérito ${ }^{118}$.

Ahora bien, incluso dejando a un lado la concepción del recurso como garantía (sobre la cual volvemos más adelante) y analizándolo sólo como un instrumento jurídico-técnico expuesto a una decisión de política legislativa, consideramos que existen buenas razones para no dar lugar a estas propuestas de supresión de la doble instancia. Bien se ha señalado que en la repetición de grados, en el aumento del número de los que deciden las contiendas se busca un término medio de las cualidades de una buena obra judicial: "compensándose defectos y méritos para que la mayor parte de las veces se hiciera la mayor cantidad de justicia posible"119. Aporta el doble grado mayores probabilidades de corregir yerros y, sobre todo, de un resultado justo del proceso, lo que desde luego no cabe desechar tan fácilmente, menos en una Justicia que se quiere rápida ${ }^{120}$ (por tanto, más expuesta a cometer errores).

Añadidamente, se olvida una cuestión básica: la importancia del juicio de hecho. Bien se ha abordado este punto señalando que la función jurisdiccional

\footnotetext{
115 Allorio, E. (1979), p. 1792.

${ }^{116}$ Sobre las concepciones que pueden servir de telón de fondo en el tema de los recursos, véase: GonZÁLEZ Castro, M. (2004), pp. 21-23.

${ }^{117}$ Véanse un par de opiniones que, hace más de treinta años, invitaban a repensar la necesidad del doble grado: Pizzorusso, A. (1978), pp. 46-47; RicCi, E. (1978), pp. 81-84. Más radical había sido antes Cappelletti. En contra, véase: Allorio, E. (1979), pp. 1783 y ss.

118 Véase: VeSCOVI, E. (1988). Los recursos judiciales y demás medios impugnativos en Iberoamérica (Buenos Aires, Ed. Depalma), p. 99.

${ }^{119}$ Beceña, F. (1933), p. 68.

${ }^{120}$ Allorio, E. (1979), pp. 1786; 1789.
} 
importa, en su esencia, una labor intelectiva que mira a la determinación de tres aspectos diversos, pero estrechamente conectados: "la elección de la norma jurídica, la precisión de los hechos y la subsunción de los hechos en la norma"121. El grado de acierto con que la declaración de la existencia de los hechos se realice condiciona el valor de las demás operaciones, que aun realizadas a la perfección desde un punto de vista lógico, pueden carecer de toda significación jurídica si por error en la fijación de aquéllos se concretan a valorar supuestos de hechos que no tienen realidad ${ }^{122}$. Dada la importancia del punto, bien se ha sostenido que no parece equilibrado asignar solamente a una de las fases del enjuiciamiento, el establecimiento y fiscalización de los hechos ${ }^{123}$. Todavía más, reconociendo las dificultades añadidas que se plantean a propósito de los modelos procesales orales, se sentencia que sin deterioro de la justicia no es posible prescindir de la segunda instancia ${ }^{124}$.

Lo que esta relación pone claramente de manifiesto es la diferencia de finalidades que están detrás de cada postura, en su estado más puro. Mientras de un lado se busca mayor expedición y celeridad ${ }^{125}$ y el ajuste a lo que se entiende como una técnica procesal pura que impondría la única instancia en los procesos orales, del otro se advierte que el proceso no solamente requiere de decisiones prontas sino también (y fundamentalmente) de resoluciones que sean de calidad, y lo serán en cuanto mayor acierto exista en el fondo, en el mérito, permitiendo decisiones más justas. Pero incluso entre autores muy enfocados en el logro de una mayor celeridad en el enjuiciamiento, se sostiene que siempre habrá necesidad de ese control superior de otras instancias de legalidad, "pero también de la motivación fáctica y del acierto o no de la lógica del judicante y de la composición valiosa de un resultado justo" 126 .

En otras palabras, y como Taruffo lo explica, existen dos formas de entender el objeto que se asigna a los procesos civiles. Este objeto puede ser a) una resolución del conflicto, o b) una resolución del conflicto mediante una decisión justa. Pues bien, si se toma la primera opción el fondo y la calidad de la decisión no son lo

\footnotetext{
${ }^{121}$ Pereira Anabalón, H. (1965). "La prueba en el recurso de apelación civil”, en Revista de Derecho y Jurisprudencia (No 6), p. 112.

${ }^{122}$ Es lo que se señala en: BeCEÑA, F. (1933), p. 69.

123 Pereira Anabalón, H. (1965), p. 113.

124 Pereira Anabalón, H. (1965), p. 113.

125 "En la base se encontraría una idea si no nueva sí de candente actualidad, cual es la eficacia de la tutela judicial y la creciente necesidad de acelerar los juicios": Calderón Cuadrado, M. Pía (2005). La segunda instancia penal (Pamplona, Ed. Aranzadi), p. 44.

${ }^{126}$ Morello, A. (2001). "Tendencia moderna hacia el proceso por audiencias", en El proceso civil moderno (La Plata, Librería Editora Platense), p. 197.
} 
importante. En cambio, si se adopta la segunda opción, el objeto de proceso es también poner fin al conflicto, pero empleando únicamente medios que se consideren justos, correctos y certeros. Desde tal perspectiva, el fondo y la calidad retoman importancia. En los hechos podrá conseguirse un mayor o menor acercamiento a esta calidad de enjuiciamiento, pero en cuanto a lo que ahora estamos analizando, lo que resulta importante es que estos propósitos orienten y determinen el funcionamiento de los mecanismos judiciales ${ }^{127}$, entre ellos, agregamos nosotros, los que ligan con el sistema recursivo. No huelga apuntar que los recursos extraordinarios, al exigir el cumplimiento de unos requisitos concretos, importan un grado de restricción que se opone al cumplimiento de estos propósitos ${ }^{128}$.

\section{c) Opciones del legislador: apelación plena v/s apelación limitada}

Una cuestión que conviene aclarar en el tratamiento del problema objeto de nuestro análisis es aquel que dice relación con las opciones que tiene el legislador a la hora de definir el ámbito de la segunda instancia. En otras palabras, el legislador procesal no está obligado a configurar la segunda instancia en un único sentido, sino que existen al menos dos posibilidades para ello, debiendo optar por la que cumpla con lograr un adecuado equilibrio entre el modelo procesal que se está recogiendo y la necesidad del control superior al que antes nos referimos. Se trata de una decisión de política legislativa que atenderá a criterios de tradición jurídica, técnica y oportunidad ${ }^{129}$.

En efecto, básicamente, existen dos modelos puros que, con el tiempo, han dado paso a modelos mixtos que combinan aspectos de uno y de otro. Estos modelos puros (o clásicos) originan la denominada apelación plena y la apelación limitada ${ }^{130}$, que respectivamente dan lugar a un novum iudicium o a una revisio prioris instantiae ${ }^{131}$.

La primera opción supone que el tribunal superior, al realizar el examen del caso, cuenta con todos los materiales de hecho y probatorios con que contó el tribunal de la primera instancia, más aquellos otros materiales que las partes han aportado en el procedimiento seguido en la segunda instancia. Vale decir, se permite a las partes, en esta configuración de la segunda instancia, adicionar

\footnotetext{
${ }^{127}$ Taruffo, M. (2009), pp. 247-248.

${ }^{128}$ GonZÁlez, M. (1998), p. 34.

129 Pérez Asenjo, A. (2008), p. 143.

${ }^{130}$ GonZález, M. (1998), p. 91.

${ }^{131}$ Ortells Ramos, M. (2009), p. 500.
} 
alegaciones de hecho y proponer y practicar nuevos medios de prueba, con lo cual el tribunal superior cuenta para tomar la decisión con elementos de los que no tuvo conocimiento el tribunal inferior ${ }^{132}$. Poco espacio, como se ve, para la preclusión.

En cambio, la segunda opción, la apelación limitada, obliga al tribunal superior a basar su examen y decisión en los mismos materiales que tuvo a su disposición el tribunal inferior, sin que las partes puedan adicionar hechos nuevos o proponer y rendir nuevas pruebas ${ }^{133}$. Con todo, y no hay que confundirse en la explicación de estas opciones, bajo este modelo de apelación limitada el tribunal superior tiene plena competencia para revisar todo lo actuado por el tribunal inferior, tanto en lo que afecta a los hechos como en lo que dice relación con las cuestiones jurídicas deducidas ${ }^{134}$. Cuestión distinta, sobre la que volveremos más adelante, es la autolimitación de los tribunales superiores en países como España, en donde con la bandera de la protección de la inmediación se ha terminado por desnaturalizar la apelación, privándola de toda su extensión en materia de control de la valoración de la prueba ${ }^{135}$.

Parece claro que optar por la primera alternativa generaría muchas más resistencias y eventuales problemas en el marco de un nuevo modelo procesal civil que apuesta por reforzar el protagonismo de la primera instancia, además de generar evidentes inconvenientes desde el punto de vista de la búsqueda de la eficiencia del proceso, desde la perspectiva del coste temporal y económico que implicaría una solución en esa dirección. En consecuencia, con mayor realismo, resulta poco debatible que la opción de la apelación limitada que circunscriba el nuevo juicio a lo ya pedido y decidido en la primera instancia, sobre los hechos alegados y las pruebas practicadas, parece ser la más razonable ${ }^{136}$, sin perjuicio de introducir las excepciones que se puedan estimar indispensables para evitar injusticias. Es el caso de la fórmula recogida por el legislador español que permite en algunos supuestos completar el material fáctico de la primera instancia, que fundamentalmente dicen relación con hechos y pruebas que no pudieron presentarse o realizarse con anterioridad de acuerdo a criterios de excepcionalidad

\footnotetext{
${ }^{132}$ Montero Aroca, J.; Flors Matíes, J. (2005). Tratado de recursos en el proceso civil (Valencia, Ed. Tirant lo Blanch), p. 242.

${ }^{133}$ Montero Aroca, J.; Flors Matíes, J. (2005), p. 242.

${ }^{134}$ Picó I Junor, J. (2009), p. 683.

${ }^{135}$ Véase: Picó I Junor, J. (2009), pp. 683 y ss.

${ }^{136}$ Calderón Cuadrado, M. Pía (2005), p. 47.
} 
que, en todo caso, impide la variación de las alegaciones que quedaron delimitadas en la primera instancia ${ }^{137}$.

\section{d) Significado y consecuencias de la alternativa del recurso extraordinario}

Cuando "en un tono dogmatizador inadmisible", como decía Alcalá Zamora ${ }^{138}$, se postula por cierto sector de la doctrina que la implantación de la oralidad en la Justicia civil debe traducirse necesariamente en el destierro y supresión de la doble instancia, por ser ésta completamente incompatible e incoherente con los objetivos y características del nuevo modelo procesal sustentado en la oralidad y la inmediación judicial ${ }^{139}$, seguidamente se plantea el modelo que se considera compatible y coherente: un recurso extraordinario que sólo permita la revisión de derecho ${ }^{140}$, sin poder modificar la base fáctica establecida en la sentencia.

La alternativa entonces es reemplazar el recurso ordinario por excelencia (la apelación), por uno extraordinario, de amplitud bastante menor. A esta descripción responde el recurso de casación (también el recurso de nulidad), a través del cual se solicita la anulación en base a motivos taxativos establecidos por el legislador. En efecto, mientras el recurso de apelación no limita el ámbito de cognición del tribunal superior, en el recurso de casación (o de nulidad) el ámbito de la

\footnotetext{
${ }^{137}$ Según lo dispone el art. 460.2 de la LEC, las posibilidades de práctica de pruebas en la segunda instancia se restringen a:

"1. Las que hubieren sido indebidamente denegadas en la primera instancia, siempre que se hubiera intentado reposición de la resolución denegatoria o se hubiere formulado la oportuna protesta en la vista.

2. Las propuestas y admitidas en la primera instancia que, por cualquier causa no imputable al que las hubiere solicitado, no hubieren podido practicarse, ni siquiera como diligencias finales.

3. Las que se refieran a hechos de relevancia para la decisión del pleito ocurridos después del comienzo del plazo para dictar sentencia en la primera instancia o antes de dicho término siempre que, en este último caso, la parte justifique que ha tenido conocimiento de ellas con posterioridad".

${ }^{138}$ Alcalá-Zamora Castillo, N. (1934). "Notas para la reforma de la ley de Enjuiciamiento Civil”, en AA. VV. Estudios de Derecho Procesal (Madrid, Ed. Góngora), pp. 172-173.

${ }^{139}$ En Chile véase: Duce, M., Marín, F. y Riego, C. (2008), pp. 62 y ss. En contra de llevar a la inmediación a un absoluto que se transforme en una exageración de sus eventuales beneficios, véase: Del Río Ferretti, C. (2001). "La revisión de los hechos mediante recurso de nulidad", en AA. VV. Seminario Reforma Procesal Penal (Santiago, Ed. ConoSur-LexisNexis), p. 284; Coloma Correa, R. (2003). "Panorama general de la prueba en el juicio oral chileno", en AA. VV. La prueba en el nuevo proceso oral (Santiago, Ed. LexisNexis), p. 33.

${ }^{140}$ Véase: Carocca Pérez, A. (2003). Manual de Derecho Procesal: Los procesos declarativos (Santiago, Ed. LexisNexis, Tomo II), pp. 71-72.
} 
competencia del tribunal queda reducido al examen de los motivos previstos expresamente en la ley ${ }^{141-142}$.

La cuestión apareja consecuencias y no es gratuita desde el punto de vista de la perspectiva de los justiciables. Bien lo ha apuntado Lorca Navarrete cuando dice que "el carácter ordinario o extraordinario del recurso incide de manera diversa sobre el acceso a la tutela judicial efectiva mediante el recurso"143. Cuando el sistema recursivo permite que conjuntamente con el recurso ordinario (apelación), se pueda acceder a otra instancia procesal ad quem mediante el recurso extraordinario, la tutela judicial efectiva es más determinante. En cambio, cuando el sistema impone que se pase directamente a la vía extraordinaria, sin existir un acceso previo a la vía ordinaria del recurso, el logro de la tutela judicial efectiva es claramente menos incisiva y penetrante ${ }^{144}$.

Por las razones expuestas es que González Castro ${ }^{145}$ no se equivoca cuando sostiene que la reducción competencial existente en todo recurso extraordinario, que impone que se debata solamente cuestiones de derecho, existiendo la regla impeditiva del análisis de lo fáctico (regla de la intangibilidad de los hechos), no satisface la concepción de un recurso como garantía que deja atrás su consideración como mero control jerárquico.

Esta opinión crítica se debe mantener, a nuestro juicio, también frente a las propuestas de dejar como único recurso contra la sentencia al recurso de nuli$\operatorname{dad}^{146}$, que a pesar de ser presentado como un mecanismo de impugnación ajeno

\footnotetext{
${ }^{141}$ Montero Aroca, J.; Flors Matíes, J. (2005), p. 41.

${ }^{142}$ Justamente las críticas se han concentrado en este aspecto del recurso de casación en aquellos sistemas que han debido operar sin recurso de apelación. "Conlleva un conocimiento muy limitado o reducido de los hechos". "El pronunciamiento en casación se debe circunscribir a la questio iuris, sin que pueda extenderse a la questio facti". En ese sentido se ha dicho que "el doble grado jurisdiccional constituye el instrumento más idóneo para corregir los eventuales errores en que haya podido incurrir el juzgador de instancia, tanto jurídicos como fácticos". Véase: AranguëÑa Fanego, C. (1994). "Proceso Penal y doble instancia", en Revista Justicia (No 1), p. 43 y p. 50.

${ }^{143}$ Lorca Navarrete, A. (2000). Tratado de Derecho procesal civil. Parte general: El nuevo proceso civil (Madrid, Ed. Dykinson), p. 1026.

${ }^{144}$ Lorca Navarrete, A. (2000), p. 1026.

145 González Castro, M. (2004), p. 191.

${ }^{146}$ No nos confundamos. No se trata de un tema exclusivamente nominativo. El recurso puede denominarse recurso de nulidad y dar muchas posibilidades, y viceversa, el recurso puede llevar el nombre de apelación y ser muy restrictivo. No alcanza con revisar la cuestión de los nombres, se debe revisar su funcionamiento y contenido. En el caso del recurso en comento, se dirá, ha demostrado excesivas limitaciones y rigorismos en su real funcionamiento.
} 
al excesivo rigor formalista propio del recurso de casación ${ }^{147}$, ha mostrado una cara bien distinta en sede procesal penal, donde opera desde hace algunos años gracias a la reforma implementada allí. En efecto, este debate que ahora nos convoca en materia civil, se produjo hace algún tiempo en sede penal, y en él uno de los puntos que más se destacó por los partidarios de este nuevo sistema recursivo fue que se configuraba un recurso de nulidad como un mecanismo de impugnación amplio, no sujeto a demasiados rigores formales, que superaba los problemas de la casación, y que cumplía con la garantía constitucional de acceso al recurso que, se agregaba, no suponía necesariamente una revisión de los hechos y, por tanto, no requería que ese recurso tuviera que ser de apelación ${ }^{148}$.

La realidad operativa del señalado recurso de nulidad, sin embargo, ha mostrado que las intenciones iniciales no se han cumplido, lo que debe servir de alerta. Se debe poner atención, aunque algunos se resistan a entenderlo, a lo que las Cortes vienen haciendo en la realidad, de lo contrario estaremos haciendo Derecho procesal de espaldas a ella. Así, la mejor doctrina no ha tardado en denunciar la irrupción del criterio muy restrictivo sumado a un excesivo rigor formal como notas distintivas del recurso de nulidad penal, materializándose una interpretación absolutamente divorciada de la genuina concepción del recurso que, desde luego, atenta contra la garantía del derecho al recurso ${ }^{149}$. Entre las razones que están detrás de esta realidad jurisprudencial es que las restricciones y mayor rigor formal estarían justificadas precisamente por tratarse de un recurso extraordinario $^{150}$, de derecho estricto ${ }^{151}$, en donde la elevación de los requisitos formales está en función de garantizar la excepcionalidad ${ }^{152}$ del recurso. Todo ello, por cierto, en el marco de una jurisprudencia que sistemáticamente advierte que a través de este recurso no es posible inmiscuirse en las cuestiones de hecho establecidas por el tribunal de la instancia ${ }^{153}$, impedimento que encuentra justificación (según se

\footnotetext{
${ }^{147}$ NúŃEz OJEDA, R. (2008), p. 213.

${ }^{150}$ Cortéz Matcovich, G. (2006), pp. 40-41.

${ }^{151}$ Cortéz Matcovich, G. (2006), pp. 42-45.

152 Cortéz Matcovich, G. (2006), pp. 51-52.

${ }^{153}$ Cortéz Matcovich, G. (2006), p. 320.
}

${ }^{148}$ Véase: Carocca Pérez, A. (2000), pp. 312 y ss.; Pfeffer Urquiaga, E. (2001). Código Procesal Penal: Anotado y concordado (Santiago, Ed. Jurídica de Chile), pp. 368-370.

${ }^{149}$ Cortéz Matcovich, G. (2006). El recurso de nulidad: doctrina y jurisprudencia (Santiago, Ed. LexisNexis), pp. 39-40. "Esta concepción restrictiva y formalista del recurso de nulidad obedece a las más variadas justificaciones, debiendo reconocerse la creatividad que en este aspecto exhibe la jurisprudencia nacional, llegándose, en casos extremos, al establecimiento de causales de inadmisión no previstas por el legislador". 
lee de las propias sentencias) en el hecho de que se frustraría la finalidad misma para la que fue instaurada la inmediación, perdiéndose la posición privilegiada del tribunal del juicio oral respecto del tribunal de alzada ${ }^{154}$ y transformándose el recurso en cuestión en una nueva instancia ${ }^{155}$, sin diferencias con el recurso de apelación.

\section{e) Significado del derecho al recurso como garantía: art. 8 CADH. Aplicación a asuntos no penales}

Una de las razones más poderosas que ha contribuido a generarle espacios a la idea de que la segunda instancia es perfectamente suprimible en el diseño de un proceso, está dada por el cambio de perspectiva que algún sector de la doctrina ha buscado instalar en el tema relativo a la segunda instancia. Desde hace algunos años se ha ido difundiendo una posición que postula dejar atrás la consideración de la segunda instancia como una de las garantías esenciales de los justiciables tal como lo venían sosteniendo, en Latinoamérica, autores tan destacados como Couture $^{156}$ y Vescovi ${ }^{157}$. El doble grado (o doble instancia) comienza a analizarse como un instrumento jurídico-técnico, lo que busca convertirlo en un criterio no necesario y prescindible ${ }^{158}$.

Como ya lo apuntamos más arriba, la necesidad de mayor brevedad, simplicidad y economía en los juicios serían las ventajas que se suelen asociar a esta propuesta. Ahora bien, tal y como lo advierte bien Calderón Cuadrado ${ }^{159}$, este nuevo enfoque que declara absolutamente prescindible a la segunda instancia ha tenido distinta suerte tratándose de los procesos civiles y los procesos penales. Mientras en estos últimos la concepción de la segunda instancia como garantía vendría

\footnotetext{
${ }^{154}$ Cortéz Matcovich, G. (2006), pp. 321-322. Señala este autor que es fácil constatar como la inmediación ha sido elevada a verdadero basamento del sistema: "Es propio del proceso oral, por imperativo del principio de inmediación, que sea el Tribunal ante el cual se realizó el juicio el que valore soberanamente la prueba y, por tanto, la credibilidad de los declarantes. El Tribunal superior, más allá de que comparta o no las conclusiones, no puede alterarlas, porque no presenció el juicio y su mirada es necesariamente mediata. Ese es el basamento del sistema reformado de procedimiento penal y a él ha de atenerse la Judicatura, lo mismo que los intervinientes, de manera que el presente recurso no puede prosperar".

155 Cortéz Matcovich, G. (2006), pp. 328 y ss.

${ }^{156}$ Considera la segunda instancia una garantía para el justiciable. Couture, E. (2002), p. 141.

${ }^{157}$ El doble examen del mérito es una garantía esencial para el justiciable en Latinoamérica. Véase: VésCovi, E. (1988), p. 99; VésCovi, E. (1981). "Los principios procesales en el proceso civil latinoamericano", en Boletín Mexicano de Derecho Comparado (Nueva Serie, Año XIV, No 40), p. 250.

${ }^{158}$ Calderón Cuadrado, M. Pía (2005), p. 44.

${ }^{159}$ Calderón Cuadrado, M. Pía (2005), p. 44.
} 
recuperando importante terreno en los últimos años, en los procesos civiles se ha reproducido más fácilmente la tesis de que existe plena libertad del legislador para configurar el proceso con o sin segunda instancia, dejando despejado el camino para instalar la única instancia en sede procesal civil.

La diferencia a la cual se alude se origina, no hay duda al respecto en la actualidad, en el papel que han cumplido los Tratados internacionales de derechos humanos constituyendo el perfil moderno del debido proceso ${ }^{160}$, los que entraron a escena como parte del derecho interno, con jerarquía constitucional, en los países que los suscribieron y aprobaron ${ }^{161}$. Entre éstos cabe nombrar el PIDCP ${ }^{162}$, la $\mathrm{CADH}^{163}$ y la $\mathrm{CEDH}^{164}$, que recogen una serie de artículos de contenido procesal, reconociendo garantías que vienen a complementar y enriquecer las ya existentes en los textos constitucionales ${ }^{165}$, entre ellas, el derecho al recurso ante un Tribunal superior que figura en el art. 8.2, h) del Pacto de San José de Costa Rica y el derecho al doble examen de la causa en toda su extensión que se desprende del art. 14.5 del PIDCP. Así, sobre la base de algunos de estos cuerpos normativos, por ejemplo, el Tribunal Europeo de Derechos humanos y el Comité de Derechos Humanos de la ONU, ha ido forzando cambios en la situación de países como España ${ }^{166}$ llegándose a afirmar que "parece claro que la travesía iniciada por la segunda instancia en este tipo de litigios no tiene, dadas las proclamaciones constitu-

${ }^{160}$ Véase: GozAÍnI, O. (2004). "El debido proceso en la actualidad", en Revista Iberoamericana de Derecho Procesal Constitucional (Proceso y Constitución) (Ed. Porrúa, Instituto Iberoamericano de Derecho Procesal Constitucional, No 2), pp. 57 y ss.

${ }^{161}$ Véase al respecto: Nogueira AlcalÁ, H. (1997a). "Los tratados internacionales en el ordenamiento jurídico chileno”, en Revista Ius et Praxis, (Año 3, No 2), pp. 27 y ss.

162 Pacto Internacional de Derechos Civiles y Políticos.

${ }^{163}$ Convención Americana de Derechos Humanos, también conocida como Pacto de San José de Costa Rica.

${ }^{164}$ Convención Europea de Derechos Humanos.

165 Destacadamente, véase: Nogueira Alcalá, H. (2007). El debido proceso en la Constitución y el sistema interamericano (Santiago, Ed. Librotecnia), pp. 9-16; NogueIRA AlCALÁ, H. (2008). Derechos fundamentales y garantias constitucionales (Santiago, Ed. Librotecnia, Tomo II), 736 pp.; Comoglio, L. (2002). "Garantías mínimas del proceso justo civil en los ordenamientos hispano-latinoamericanos", en Revista Iberoamericana de Derecho Procesal (No 2) pp. 217 y ss.; Comoglio, L. (2008). "Garantías constitucionales y proceso justo (modelos comparados)", en Revista Peruana de Derecho Procesal (Ed. Communitas, Vol. XI), pp. 7 y ss.

166 Véase: Calderón Cuadrado, M. Pía. (2008). “Quince años de decisiones del Comité de Derechos Humanos de Naciones Unidas. España y el sometimiento de la sentencia penal condenatoria a un tribunal superior", en Arangǘña Fanego, C. y Sanz Morán, A. (coordinadores) La reforma de la Justicia Penal: aspectos materiales y procesales (Valladolid, Ed. Lex Nova), pp. 267-322; Comité de Derechos Humanos de la ONU, Dictamen de 20 de julio de 2000, caso Cesario Gómez Vásquez. Página Justicia Constitucional en Iberoamérica. Instituto de Derecho Público Comparado, Universidad Carlos III, España. Disponible en: http:// www.uc3m/inst/MGP/JCI/04-no-es-casación.htm 
cionales e internacionales por todos conocidas, vuelta atrás"167. Pues bien, lo propio ha ido logrando, por estos lados, la jurisprudencia de la Corte Interamericana de Derechos Humanos ${ }^{168}$.

Ocurre sin embargo que, como se dijo antes, tratándose de la reforma procesal penal, se suprimió el recurso de apelación contra la sentencia definitiva, instaurándose un recurso de nulidad que, según se argumentó en su momento, cumplía con la garantía constitucional de acceso al recurso que, se decía, no suponía necesariamente una revisión de los hechos y, por tanto, no requería que ese recurso tuviera que ser de apelación ${ }^{169}$. Sostener aquello al día de hoy parece bastante más complejo si se revisa la jurisprudencia de la Corte Interamericana de Derechos Humanos. En efecto, en el caso Herrera Ulloa (vs Costa Rica) ${ }^{170}$, que marca un cambio en la intensidad y extensión que se reconoce a la garantía ${ }^{171}$, la Corte primero nos recuerda que "no basta con la existencia formal de los recursos sino que éstos deben ser eficaces, es decir, deben dar resultados o respuestas al fin para el cual fueron concebidos"172, y luego sentencia que "independientemente de la denominación que se le dé al recurso existente para recurrir un fallo, lo importante es que dicho recurso garantice un examen integral de la decisión recurrida", lo que la llevó a dejar sin efecto en todos sus extremos la sentencia emitida por el Tribunal penal del primer Circuito Judicial de San José, a declarar que los recursos de casación interpuestos en el caso "no satisficieron el requisito de ser un recurso amplio de manera tal que permitiera que el tribunal superior realizara un análisis o examen comprensivo e integral de todas las cuestiones debatidas y analizadas en el tribunal

167 Calderón Cuadrado, M. Pía (2005), p. 45. Una opinión que sostiene que no existe una verdadera necesidad de generalizar la apelación (quizás conveniencia), siendo suficiente con la casación, en: BONET Navarro, J. (2009). "Presunción de inocencia a favor del actual recurso de casación", en Revista La Ley Penal (No 64), pp. 2 y ss.

${ }^{168}$ Nogueira Alcalá, H. (2007), pp. 13-14.

${ }^{169}$ Carocca Pérez, A. (2000), pp. 312 y ss.

${ }^{170}$ Sentencia de 2 de julio de 2004. Aunque ya antes encontramos señales, aunque menos explícitas: Caso Castillo Petruzzi (vs Perú), con sentencia de 30 de mayo de 1999. Véase: Toro Justiniano, C. (2009), p. 117. En el caso Castillo Petruzzi resulta especialmente interesante leer el voto concurrente del juez Carlos De Roux Rengifo, quien sostiene contundentemente que en el caso se viola la garantía del art. $8.2 \mathrm{~h}$ ) no porque los tribunales superiores fueran militares, sino porque éstos no revisaron verdaderamente la causa, ya que no actuaron reexaminando los hechos, ponderando el valor del acervo probatorio, recaudando las pruebas adicionales que fueran necesarias, recalificando jurídicamente los hechos de acuerdo al ordenamiento jurídico y fundamentando dicha calificación. Véase: González Castro, M. (2004), pp. 248 y ss.

${ }^{171}$ Por mucho que se le haya intentado bajar el perfil y la importancia: DuCE, M. y RIEGO, C. (2007), pp. 509 y ss.

${ }^{172}$ Toro Justiniano, C. (2009), p. 117. 
inferior"173, y ordenar al Estado de Costa Rica a "adecuar su ordenamiento jurídico interno a lo establecido en el art. 8.2, h) de la Convención Americana de Derechos humanos, en relación con el art. 2 de la misma"174, con lo que se pone muy en sintonía con algunas decisiones emitidas por el Comité de Derechos Humanos del PIDCP en contra de España ${ }^{175}$.

En este caso resulta interesante leer el voto concurrente del juez Sergio García Ramírez, quien descartando al recurso de revisión extraordinario como un mecanismo de impugnación que sea suficiente para cumplir las exigencias del art. 8.2 h), a la pregunta sobre qué exigencias cabe extraer de esta garantía para concretar los criterios de la máxima protección del individuo, asegurar el derecho a una sentencia formal y materialmente justa y ajustarse a los dictados del principio de inocencia, responde que el recurso "debe ser uno que efectivamente permita al superior entrar en el fondo de la controversia, examinar los hechos aducidos, las defensas propuestas, las pruebas recibidas, la valoración de éstas, las normas invocadas y la aplicación de ellas" ${ }^{176}$.

Es claro, aunque no agrade a quienes diseñaron el sistema recursivo del proceso penal reformado ${ }^{177}$, la Corte Interamericana está considerando que el derecho al recurso ante el tribunal superior "debe ser una reconsideración de tendencia general de las cuestiones de hecho y de derecho (meritum causae) y no sólo una querella nullitatis", debiendo gozar de la amplitud antes apuntada, por tanto, resultando preceptivo que permita revisar los hechos y la valoración de las pruebas ${ }^{178}$. Las cuestiones de hecho "deben encontrarse en el marco de la vía impugnativa a los fines de dar satisfacción a la garantía" ${ }^{179}$, lo que a la luz de lo que hemos sostenido respecto del recurso de nulidad penal lo deja en una situación, al menos, inconfortable, con no pocas dificultades para alcanzar el estándar impuesto: "El recurso como garantía es la posibilidad de alzarse contra ambos errores en que puede incurrir la jurisdicción, en hechos y derecho "180. Desde esta perspectiva aparecen pocas dudas de que un recurso ordinario debe ser la vía válida para dar satisfacción a la garantía del

\footnotetext{
${ }^{173}$ Toro Justiniano, C. (2009), pp. 120-121.

${ }^{174}$ Nogueira Alcalá, H. (2007), p. 108.

175 Calderón Cuadrado, M. Pía. (2008), pp. 267 y ss.; Nogueira Alcalá, H. (2007), p. 107.

${ }^{176}$ Toro Justiniano, C. (2009), p. 121.

177 Duce, M. y Riego, C. (2007), pp. 510-514.

178 Nogueira Alcalá, H. (2007), p. 106.

${ }^{179}$ González Castro, M. (2004), p. 233.

${ }^{180}$ GonzÁlez Castro, M. (2004), p. 238.
} 
derecho al recurso ${ }^{181}$, por lo que no obstante la Corte no se atreva a señalarlo esta garantía no podría sino interpretarse como la garantía de la doble instancia ${ }^{182}$. Es la simple constatación, si se quiere ver así, que "el debido proceso tiene un contenido que evoluciona", incorporando nuevas dimensiones o ampliando los alcances que tradicionalmente se asignaban a sus elementos ${ }^{183}$, imponiendo que el examen de la sentencia de primera instancia sea in facto et in iure.

La pregunta que surge de inmediato es si esta garantía del derecho al recurso (con este estándar reforzado declarado por la Corte Interamericana en el fallo citado) es predicable respecto del proceso civil. A estas alturas del desarrollo de la jurisprudencia de la Corte Interamericana consideramos que la respuesta no puede ser sino afirmativa, lo que debe tener consecuencias en el diseño del sistema recursivo previsto en el Proyecto de nuevo CPC. En efecto, como se ha anotado entre nosotros, "un proceso debe ser debido o justo independientemente de si lo que se discute ha sido definido como penal, laboral, familiar o comercial"184. De este modo, tratándose de las exigencias contenidas en las cláusulas posteriores de los Tratados internacionales citados (por ejemplo, el art. 8.2 de la CADH), en donde no se señala expresamente su aplicación a los procesos que recaen en la sustanciación de procesos penales o para la determinación de derechos de orden civil, laboral, fiscal o de cualquier otro carácter, también han sido comprendidas por la Jurisprudencia de estos Tribunales como garantías que deben existir en los procesos no penales, entre ellos los procesos civiles, reforzando y enriqueciendo la idea de debido proceso en dicho fuero ${ }^{185}$. No cabe otra interpretación posible, así lo ha declarado explícitamente la propia Corte Interamericana ${ }^{186}$. Así se desprende, incluso, como algún autor ha demostrado, de un análisis literal de la norma ${ }^{187}$.

${ }^{181}$ González Castro, M. (2004), p. 239.

${ }^{182}$ González Castro, M. (2004), pp. 253 y 285

${ }^{183}$ Duce, M., Marín, F. y Riego, C. (2008), p. 26.

${ }^{184}$ Duce, M., Marín, F. y Riego, C. (2008), p. 30.

${ }^{185}$ Duce, M., Marín, F. y Riego, C. (2008), p. 31.

${ }^{186}$ Duce, M., Marín, F. y Riego, C. (2008), p. 33.

${ }^{187}$ Véase al respecto: GonZález CASTRO, M. (2004), pp. 268 y ss. Explica González Castro que la problemática del numeral 2 del art. 8 de la $\mathrm{CADH}$ puede resolverse atendiendo, incluso, a la interpretación estrictamente literal del precepto. El numeral 1 consagraría garantías genéricas de estilo clásico, sin ingresar en un detalle pormenorizado de la implicación de cada una de ellas. Se opta por una enunciación de tipo clásica y genérica "para todo tipo de procesos". Tratándose del numeral 2, señala el autor que cuenta con dos oraciones bien determinadas y separadas por un punto. Este numeral comienza diciendo "toda persona inculpada de delito...", tras lo cual consagra explícitamente el estado de inocencia, el que se ha formulado siempre desde la óptica penalista. La segunda oración del numeral 2 prescribe que "durante el proceso toda persona...", desapareciendo la expresión "inculpada de delito", reforzando que goza de estas garantías mínimas "toda persona”. Además, 
La cuestión del juzgamiento en doble o única instancia era una cuestión de política legislativa (regla técnica de la actividad de sentenciar, como postula Alvarado Velloso ${ }^{188}$ que se traducía en un derecho fundamental de configuración legal ${ }^{189}$ hasta que la garantía del derecho al recurso (con el contendido y la extensión que ya se ha anotado) ha sido reconocida con rango constitucional, gracias a la incorporación de los Tratados internacionales sobre derechos humanos en el derecho interno ${ }^{190}$. Una reforma que no cumpla con la garantía acá descrita y el estándar impuesto para ella no sería, a nuestro juicio, constitucionalmente admisible y desde luego que atentaría contra el principio favor libertatis que, como se sabe, otorga fuerza expansiva a los derechos ${ }^{191}$. Con todo lo dicho, prescindir del encuadre constitucional parecería muy poco razonable, lindante con la obstinación técnico-dogmática. En otras palabras, la garantía procesal del derecho al recurso no se puede cumplir con cualquier fórmula convencional ${ }^{192}$, ha de producirse según el mandato constitucional complementado, según se ha evidenciado, por lo dispuesto en los Tratados internacionales.

\section{LA NO TAN “IMPOSIBLE” CONVIVENCIA ENTRE LA ORALIDAD, EL RECURSO DE apelaCión y la doble instancia. De lo teÓRICAMENTE “INCOMPATIBLE” A LO PRÁCTICAMENTE RACIONAL, POSIBLE Y ÚTIL}

\section{a) La oralidad, los mayores poderes oficiosos del juez y la garantía de revisión}

La oralidad viene siendo considerada por algún sector de la doctrina como producto de la corriente publicista del proceso civil ${ }^{193}$, propugnadora de un aumento

agrega, si estas garantías mínimas que se recogen en la segunda parte del numeral 2 fueran aplicables sólo a los procesos penales, no tendría razón de ser el haber distinguido en la misma norma tres numerales más que consagran principios propiamente penales como las signadas con el número 3 y 4 . Por lo tanto, "de la misma textualidad del numeral 2 del art. 8 de la Convención, surge que estas garantías conforman un plexo de reglas que son de aplicación a todo proceso, sin importar la materia que en él se debata”.

${ }^{188}$ Alvarado Velloso, A. (2005). Garantismo procesal contra actuación judicial de oficio (Valencia, Ed. Tirant lo Blanch), pp. 288-289.

${ }^{189}$ De la Oliva Santos, A. (1997), p. 973.

${ }^{190}$ En este sentido se ha dicho que la opción la haya efectuado el constituyente no cambia el carácter de regla, pero sí impide al legislador procesal desconocer la opción efectuada por el constituyente. GonZÁLEZ Castro, M. (2004), p. 289.

${ }^{191}$ Según esta fórmula, en caso de duda, debe optarse por la interpretación que mejor proteja asegurando y garantizando los derechos humanos en su conjunto. Véase: Nogueira AlCalá, H. (1997b). Dogmática constitucional (Talca, Ed. Universidad de Talca), p. 146.

${ }^{192}$ Lorca Navarrete, A. (2008). "La garantía procesal del derecho al recurso", en Revista Vasca de Derecho Procesal y Arbitraje (Vol. 20, No 3), p. 598.

${ }^{193}$ Denunciando este fenómeno, véase: Palomo Vélez, D. (2009), p. 653. 
de los poderes del juez como parte de la solución de los problemas que aquejan a este proceso ${ }^{194}$. La revisión del Proyecto de nuevo CPC en esta perspectiva muestra que sus redactores no han resistido la tentación de tomar una opción hacia el aumento de los poderes oficiosos del juez civil ${ }^{195}$.

Esta constatación constituye, a nuestro juicio, otra razón (de no poca importancia) por la cual aparece como escasamente razonable prescindir de la amplitud de control que permite un recurso ordinario como la apelación para embarcarse en una aventura mucho más acotada y limitada en donde, ya lo vimos, los perjudicados son los justiciables que buscan la revisión más integral de la decisión recurrida. Es que si a la instalación de un juez con amplios poderes de dirección no sólo formales sino también materiales, se le suma la supresión de la segunda instancia, contemplándose sólo un recurso extraordinario de nulidad (cuya suerte en la práctica ya podemos imaginar de acuerdo a lo acontecido en materia penal), el escenario para las partes empeora sacrificando garantías y principios fundamentales (como el resguardo de la imparcialidad judicial), concretando aquello que debe evitarse: una reformatio in peius.

\section{b) El nuevo juicio y la grabación audiovisual como un soporte que permite} compatibilizar oralidad y segundo grado: la oralidad e inmediación secundaria

El tono dogmatizador empleado por algunos para abordar el tema objeto de este trabajo podría arrojar frutos sólo si no se lograra entender por nuestro legislador lo que está en juego detrás de las alternativas que la doctrina pone a su disposición: la garantía del derecho al recurso. Podría fructificar si con ignorancia supina cometiera el error de confundir cuestiones que, según hemos explicado, son claramente diversas: los principios procesales y las reglas, mezclando, como se diría popularmente, peras con manzanas. Sólo así se entendería que el legislador terminara contemplando un sistema recursivo restringido, con el solo afán de proteger la oralidad y la inmediación propias del modelo oral que se quiere recoger.

$\mathrm{Si}$, en cambio, se comprende la garantía que está en juego y se distinguen correctamente los elementos que son disponibles de los que no lo son, el escenario se despeja notablemente permitiendo al legislador realizar un trabajo de mejor calidad. En efecto, tratándose de salvar la eventual incompatibilidad existente entre el modelo oral con inmediación judicial y la sobrevivencia de la segunda

\footnotetext{
${ }^{194}$ Una interesante revisión de este tema en: ETXEBERRÍA GURIDI, J. (2003). Las facultades judiciales en materia probatoria en la LEC (Valencia, Ed. Tirant lo Blanch), 413 pp.; Montero AroCA, J. (2001). Los principios politicos de la nueva LEC: Los poderes del juez y la oralidad (Valencia, Ed. Tirant lo Blanch), 190 pp.

195 Palomo Vélez, D. (2009), p. 654.
} 
instancia, junto con tener presente las prevenciones efectuadas a lo largo de estas líneas, especialmente las que dicen relación con la invitación a no idealizar la inmediación y aquéllas con las que destacamos la mayor importancia de la prueba documental en materia civil, cabe tener presente que durante todos los años de vigencia del actual CPC (más de un siglo) nadie ha objetado la existencia de una segunda instancia desde la perspectiva de un eventual daño a la inmediación judicial y bien se sabe que las Cortes deciden de acuerdo a las actas y materiales recogidos en el expediente.

Puestas las cosas en su lugar y en su justa dimensión, debemos avanzar para señalar que la convivencia entre la oralidad y la segunda instancia es perfectamente posible (posible y necesaria, se puntualiza) ${ }^{196}$, tal vez no con la pureza técnica que postulan algunos, pero sí bajo un esquema posible en una reforma que nace en el siglo XXI. Nos referimos a la (denominada) oralidad e inmediación secundarias, esto es, a las posibilidades que brinda la tecnología de cara al mejor funcionamiento y eficacia del proceso ${ }^{197}$, concretamente a la posibilidad de que a través de filmaciones (grabaciones) por medios audiovisuales ${ }^{198}$ se atenúen los problemas que se apuntan en la relación entre la doble instancia y un modelo procesal oral. Nótese que abogamos por la documentación audiovisual de lo acontecido en la o las audiencias de prueba, puesto que consideramos que así se permite a los miembros del tribunal superior no sólo oír lo acontecido, sino que también observarlo ${ }^{199}$.

Es cierto que a través de estas grabaciones no se lograría situar al tribunal ad quem en idéntica posición a la que tuvo el tribunal a quo cuando dictó sentencia; "el tribunal de apelación necesariamente se encontrará en situación diversa a la disfrutada por el órgano a quo"200. Difícilmente podrá realizar respecto de las pruebas personales un juicio de credibilidad similar al efectuado por el inferior y llegar a las mismas percepciones y apreciaciones de quien reconoció el objeto o persona, ya que no ha visto ni oído todo lo que pudo percibir el juez del tribunal

\footnotetext{
${ }^{196}$ Andrés IbÁÑEZ, P. (2003), p. 64.

197 Amrani-MekKi, S. (2008). "El impacto de las nuevas tecnologías sobre la forma del proceso civil", en Carpi, F. y Ortells, M. (editores) Oralidad y escritura en un proceso civil eficiente (Valencia, Universidad de Valencia, Tomo I), pp. 96 y 107 y ss.

${ }^{198}$ Véase al respecto: Gómez MarTínez, C. (2003), "La grabación del sonido y de la imagen en los juicios civiles: del juez lector al juez espectador" en Revista Jueces para la Democracia (No 48), pp. 81-87.

199 Peyrano, J. (2008). "La prueba entre la oralidad y la escritura", en Carpi, F. y Ortells, M. (editores) Oralidad y escritura en un proceso civil eficiente (Valencia, Universidad de Valencia, Tomo I), p. 168.

${ }^{200}$ Calderón Cuadrado, M. Pía. (2004), p. 835.
} 
inferior a través de sus sentidos ${ }^{201}$. Pero esta crítica junto con llevar la inmediación a un absoluto cercano a la idealización (a ello ya nos referimos críticamente), no sopesar adecuadamente los elementos involucrados, desconocer que el tribunal superior siempre se verá afectado por "la mayor lejanía cronológica, espacial y psicológica del hecho"202 (es una realidad compartida por todos los medios de impugnación), no destaca el inmenso salto cualitativo que representa esta situación respecto del sistema enteramente escrito que hasta hoy nos rige ${ }^{203}$. En efecto, como se ha destacado, los miembros del tribunal superior pueden de este modo revisar las declaraciones de las partes, testigos y peritos, y contrastarlas con la motivación fáctica ${ }^{204}$. En el mismo sentido y con el propósito de mantener el debate en un carril razonable, se ha dicho: "resulta indudable que el contacto directo con las partes y las pruebas personales producen una serie de inconscientes sensaciones, pero entiendo que éstas, como las que se inducen de la valoración conjunta de la prueba, las reglas de la experiencia y todo aquello que nos permite crear nuestro convencimiento sobre cómo han sucedido unos hechos, deben quedar perfectamente reflejados en la valoración que de la prueba se haga en la sentencia. De esa forma se permite que en apelación se haga un juicio crítico sobre la misma que junto con el visionado de las pruebas permita discrepar o no de aquella valoración mediante unas explicaciones concretas al caso, fundamentadas y ajustadas perfectamente a una racionalidad que se entiende inherente tanto al juzgado de instancia como al de apelación "205.

Aún así, se debe admitir, no será lo mismo ni pretendemos probar lo contrario. Sin embargo, se ha señalado que es necesario eliminar una falacia (para evitar buscar un imposible), cual es que el juicio de primera instancia sería realmente repetible por el procedimiento de reiterar la totalidad de las actuaciones ante el tribunal superior. Como bien se explica, tales vicisitudes son irrepetibles en las condiciones en que se dieron, por el efecto condicionante que la primera experiencia procesal tendría en las representaciones y actitudes de los partícipes, incluso en el mismo juzgador que "nunca lo sería ya de primera instancia". De este modo, asumido esto, "el dato base que hay que tomar en consideración no es que el juez o tribunal de

\footnotetext{
${ }^{201}$ Calderón Cuadrado, M. Pía. (2004), p. 835.

${ }^{202}$ AranguëNA Fanego, C. (1994), p. 56.

${ }^{203}$ Se ha dicho que los modernos medios técnicos de reproducción desvanecen muchos de los inconvenientes de la oralidad, pero no todos, puesto que escuchar y volver a escuchar, como ver y volver a ver, además de ser contrario a hábitos sumamente arraigados, no es lo mismo que estudiar textos escritos: De la Oliva SANTOS, A. et al. (2004), p. 78.

${ }^{204}$ Picó i Junoy, J. (2009), p. 686.

205 Pérez Asenjo, A. (2008), p. 155.
} 
segunda instancia vaya a carecer de contacto directo con las fuentes personales de prueba", sino que este contacto, "en condiciones de cierta genuinidad", sólo está disponible y al alcance de un primer juzgador, cuya decisión no puede quedar blindada, por esta sola circunstancia, a un control jurisdiccional ${ }^{206}$ que, desde luego, satisfaga las exigencias que ya hemos podido revisar.

Con todo, es una situación que sería muy superior a la actual como bien lo reconoce la doctrina ${ }^{207}$. Que se trate de una oralidad y una inmediación "secundarias" será, en cualquier caso, "el precio que se debe pagar por el valor de la doble instancia, si queremos salvar la esencial función garantista" ${ }^{208}$ que reconocemos en ella.

\section{c) A la hora de conciliar la oralidad y el doble grado, un eventual problema: que se termine desvirtuando la segunda instancia por la imposición de limitaciones}

Aunque de lo dicho hasta este punto pueda desprenderse una asimilación entre el derecho al recurso como garantía procesal asegurada por la Constitución y tratados internacionales y el derecho al recurso de apelación, insistimos en algo que apuntamos un poco más atrás: no se trata de un tema de nombres. El recurso puede denominarse recurso de nulidad y dar muchas posibilidades de revisión, y viceversa, el recurso puede llevar el nombre de apelación y resultar muy restrictivo. No es suficiente revisar la cuestión de los nombres, sino que se debe revisar su funcionamiento real como también el contenido que el legislador ha previsto para el recurso ${ }^{209}$.

\footnotetext{
${ }^{206}$ Andrés IbáŃ̄EZ, P. (2003), p. 64.

207 "La reproducción de la imagen y el sonido de lo ocurrido en el curso de la audiencia de prueba posibilita una inmediación sensorial (el juez observa y escucha, lo sucedido) que puede ser no presencial (el juez no estaba físicamente presente mientras se actuaba la prueba). Dicho tipo de inmediación (la sensorial, no presencial) conserva la mayoría de los atributos de la inmediación física". "La reproducción audiovisual filmada posibilita al tribunal de apelación revisar la sesión probatoria, zanjando buena parte de los óbices puestos en miras a impedir que la instancia revisora se interne en la valoración de los hechos de la litis". PeYrano, J. (2008), pp. 165 y 169. Véase también: MarTín Brañas, C. (2008) "La oralidad y la segunda instancia civil", en Carpi, F. y Ortells, M. (editores) Oralidad y escritura en un proceso civil eficiente (Valencia, Universidad de Valencia, Tomo I), pp. 468-469.

${ }^{208}$ Ferrajoli, L. (1996/B). "Los valores de la doble instancia y de la nomofilaquia”, en Revista Nueva Doctrina Penal (Ed. Del Puerto), p. 448.

${ }^{209}$ Un poco más adelante damos cuenta de la situación, reformada, del recurso de apelación en Alemania. Nos parece un buen ejemplo de lo que estamos advirtiendo: no basta revisar la cuestión nominativa, sino que se debe revisar también el contenido que el legislador ha previsto para el recurso. Si el legislador termina restringiendo más allá de lo razonable la amplitud propia del recurso de apelación, éste pasa a adquirir otra naturaleza, en perjuicio, claro está, del respeto a la garantía procesal involucrada.
} 
Este es uno de los problemas que, como consecuencia del estado de confusión existente en la materia, puede presentarse en los sistemas que, reformados, apuestan por la introducción de la oralidad y la inmediación como reglas definidoras del nuevo proceder. Puede comenzar a reproducirse, como ha acontecido en España, una doctrina jurisprudencial según la cual la valoración de las pruebas corresponde al juez de la instancia, ya que por su posición de inmediación y percepción directa de las pruebas se encuentra en una situación más favorable para efectuar esta función, en la que pasa a ser difícilmente sustituible por quien no las presenció, especialmente cuando se trata de las denominadas pruebas personales como lo es la testimonial ${ }^{210}$. En esa lógica, la revisión efectuada en sede de apelación se deberá limitar, se agrega, a examinar la regularidad y validez procesal en la producción de las pruebas, y en cuanto a su valoración, sólo a verificar si las conclusiones que el juez ha obtenido resultan congruentes con sus resultados, y se ajustan a los criterios generales del razonamiento lógico, según las reglas de experiencia comúnmente admitidas ${ }^{211}$, esto es, se instala la doctrina mediante la cual, salvo que la valoración del juez de primera instancia sea ilógica, irracional, absurda u opuesta a las reglas de la sana crítica, ella se respeta y no se puede variar. Bajo pretexto de proteger la inmediación se termina desnaturalizando el recurso de apelación, que por su carácter y naturaleza no tiene esta limitación, relegando la posibilidad de una apelación verdaderamente revisora de lo efectuado por el juez a $q u o^{212}$ que cumpla los estándares del derecho al recurso.

Se trata de una autolimitación de lo controlable, a nuestro juicio, que no es razonable, que se opone al carácter y naturaleza ordinaria, plena y amplia del recurso de apelación, lo termina transformando en un recurso extraordinario ${ }^{213}$, siendo incluso factible plantear alguna duda si la verdadera razón de esta doctrina radica en el respeto que se declara hacia el modelo oral, o bien se trata de una justificación más sencilla como lo puede ser el hecho de que los tribunales superiores se consideren sobrepasados por el trabajo. Respecto a esta cuestión, no cabe otra respuesta que entender que los tribunales superiores no deben limitarse a corregir errores manifiestos o groseros de los tribunales inferiores, sino que en la búsqueda de la solución más acertada y justa para el justiciable, debe valorar de nuevo la prueba, sin estar vinculado a lo razonado y valorado por el juez inferior,

${ }^{210}$ Véase: Calderón Cuadrado, M. Pía. (2004), pp. 839-840.

${ }^{211}$ Calderón Cuadrado, M. Pía. (2004), p. 840.

212 Pérez Asenjo, A. (2008), p. 148.

${ }^{213}$ Picó i Junoy, J. (2009), p. 692. 
ya que la revisión abarca todo el material fáctico y jurídico ${ }^{214}$. Una contribución para lograr conciliar la oralidad y el doble grado en donde se pueda cumplir plenamente la función revisora deben ser las grabaciones audiovisuales a las cuales nos referimos antes. De ese modo, se debe lograr un adecuado equilibrio ${ }^{215}$ de los intereses en juego, privilegiando, como no podía ser de otro modo, la garantía por sobre la regla.

\section{d) Un vistazo a las opciones adoptadas en la Justicia de familia $y$ en la Justicia del Trabajo}

Tratándose de las reformas procesales que siguieron a la efectuada a la Justicia criminal, la opción por la oralidad, la inmediación judicial y la concentración permanecen como inspiración del legislador, aunque una diferencia importante es que no se contempla ya un tribunal colegiado para la decisión del juicio oral. Pues bien, en lo que dice relación con el abordaje del tema de los recursos, la solución es distinta tanto en la reforma a la Justicia de familia como en la realizada a la Justicia del trabajo.

En efecto, en el caso de la reforma a la Justicia de familia (Ley No 19.968, de 2004), la apuesta por la oralidad (art. 10), la concentración (art. 11) e inmediación (art. 12) es bien conocida, y ella no impidió que el legislador consagrara como apelables las sentencias definitivas de primera instancia (art. 67.2) ${ }^{216}$. En cambio, en la Ley No 20.087, de 2006 (entre otros cuerpos legales: Leyes $\mathrm{N}^{\circ}$ s. 20.022, $20.023,20.252$ y 20.260), a través de la cual se reformó la Justicia laboral también en el sentido de introducir la oralidad y sus reglas tradicionalmente asociadas ${ }^{217}$, la situación fue resuelta de un modo distinto, y tras el invento fallido de la "apelación laboral ${ }^{218}$ se terminó eliminando el recurso de apelación contra el fallo de primer

\footnotetext{
${ }^{214}$ Pérez Asenjo, A. (2008), p. 157. “...respecto de la revisión del material fáctico entiendo que se produce una desnaturalización del derecho al recurso, como segunda instancia de revisión íntegra del primer fallo, si negamos el control fáctico de lo discutido, esto es, si impedimos la nueva valoración del resultado probatorio".

215 Picó I Junoy, J. (2009), p. 691.

${ }^{216}$ En contra de esta decisión, señalando que se trata de un mecanismo de recursos incoherente con el modelo procesal oral instaurado, véase: Meneses PAcheco, (2009a), pp. 21-24.

${ }^{217}$ Véase: Orellana Torres, F. (2008). Comentario al nuevo proceso laboral, $2^{\mathrm{a}}$ edición actualizada (Santiago, Ed. Librotecnia), p. 11; Walter Díaz, R., Lanata Fuenzalida, G. (2008). Régimen legal del nuevo proceso laboral chileno, $4^{\mathrm{a}}$ edición actualizada (Santiago, Ed. LegalPublishing), pp. 87 y ss.

${ }^{218}$ Fue la Ley No 20.260 la que rectificó la decisión inicial de contemplar en el nuevo proceso un recurso de apelación "laboral", que de apelación, la verdad sea dicha, tenía sólo su nombre. Sólo podía tener por objeto revisar la sentencia de primer grado cuando ésta haya sido dictada con infracción de normas; revisar los hechos
} 
grado poniendo en su lugar un recurso extraordinario de nulidad (arts. 477 a 482) muy en sintonía con el previsto en el proceso penal, contemplándose dos clases de causales -general y específicas- que se facultan, en cuanto a los hechos, fundarlo en la infracción manifiesta en la sentencia de las normas que rigen la valoración de la prueba según las reglas de la sana crítica (art. 478, b). Damos por reproducida en este punto nuestra posición respecto de la limitación que representa la opción legislativa por un modelo de única instancia y por un recurso de derecho estricto, más si se atiende a la experiencia acumulada en la jurisprudencia procesal penal.

\section{e) Derecho comparado: España, Uruguay (Código Modelo), Perú y Alemania}

Habiendo defendido desde distintos frentes no sólo la conveniencia, sino que la necesidad de contemplar un recurso suficientemente amplio que permita la plena revisión de lo resuelto por el tribunal de primera instancia, queda por tomar nota sobre qué camino han seguido los legisladores de países que normalmente nos sirven de referentes en materia de reforma o bien en países de nuestro entorno que ya cuentan con una legislación procesal que ha dejado atrás el modelo desesperantemente escrito. En esta perspectiva, a fin de verificar cuál es la situación en el derecho comparado, hemos tenido a la vista los siguientes países: España, Uruguay, Perú y Alemania.

Si la mirada la ponemos en España, conocida entre nosotros es su razonable (y no maniquea) apuesta hacia la oralidad en la Justicia civil materializada a través de la LEC $1 / 2000^{219}$. La pregunta cuya respuesta ahora debe interesar es si esta decisión de introducir mayores grados de oralidad al fuero civil significó prescindir de la segunda instancia y desechar el recurso de apelación contra las sentencias dictadas por el tribunal de primer grado. La respuesta es claramente negativa, sin perjuicio de los problemas de funcionamiento apuntados antes, respecto de los cuales la mejor doctrina ya ha instado por su superación a fin de permitir a la apelación servir de instrumento de revisión integral de lo resuelto en la primera instancia.

En el caso de Uruguay, el Código General del Proceso, que entra en vigencia en 1989, bajo la inspiración de las reglas de oralidad, inmediación, concentración,

declarados como probados por el tribunal de primera instancia cuando se advierta que en su determinación se han infringido, en forma manifiesta, las normas sobre apreciación de la prueba conforme a las reglas de la sana crítica; y alterar la calificación jurídica de los hechos, sin modificar las conclusiones fácticas del tribunal inferior. Véase: Walter Díaz, R., Lanata Fuenzalida, G. (2008), p. 230.

${ }^{219}$ Palomo Vélez, D. (2008), 689 pp.; De la Oliva Santos, A. (2009), pp. 63 y ss.

Véase: http://noticias.juridicas.com/base_datos/Privado/11-2000.html 
consagrado al juez como director del proceso, tampoco prescinde de la apelación y la segunda instancia (art. 344). Se asegura la doble instancia ${ }^{220}$, existiendo Tribunales de Apelaciones en lo civil. Pero la experiencia reformadora uruguaya, siendo exitosa, no interesa tanto en sí misma, sino porque ha constituido una instancia que ha permitido constatar más allá del papel la posibilidad de llevar a la realidad lo dispuesto en el Código Modelo, referente en los procesos de reforma de la Región. Siendo el uruguayo el modelo recogido en el Código Modelo de $1988^{221}$, casi sobra señalar que allí también se consagra la doble instancia como eje del sistema recursivo ${ }^{222}$, ello no obstante que, como se sabe, este referente también ve en la oralidad y el proceso por audiencias un sistema que debe expandirse entre los países de la Región ${ }^{223}$.

El CPC peruano, de 1993, que también optó por introducir la oralidad en el proceso civil, recogiendo sus reglas conexas de inmediación y concentración, otorgando al juez importantes poderes de dirección, tampoco desecha la garantía del doble grado. Al contrario, el art. X del citado Código recoge el principio de doble instancia, desarrollando a partir del art. 364 su regulación.

Finalmente, tratándose del caso alemán, donde también se recoge el modelo de proceso civil por audiencias ${ }^{224}$ y el recurso de apelación contra la sentencia dictada por el tribunal de primera instancia, debe anotarse que se han producido novedades relevantes en el sistema de recursos previsto en la Zivilprozessordnung (ZPO) materializadas en una Ley de reforma del 2002 225 . Para comprender los cambios introducidos a través de esta reforma, debe tenerse presente que desde hace años el objetivo principal de los alemanes está en la simplificación y aceleración del proceso (además de alivianar la carga de trabajo a los tribunales) que, por la

${ }^{220}$ Véase: Pereira Campos, S. El proceso civil ordinario por audiencias (...). Op. cit., pp. 40, 54, 64, 128 y 129; Pereira Campos, S. (2006), pp. 748 y ss.

Véase: http://www.acnur.org/biblioteca/pdf/0957.pdf

${ }^{221}$ Pereira Campos, S. (2008), p. 30.

${ }^{222}$ Véase: (1994). "Iberoamericano de Derecho Procesal”, El Código Procesal Civil Modelo para Iberoamérica (Caracas, Academia de Ciencias Políticas y Sociales, Serie Estudios) pp. 142-147; (1989). Proyecto de Código Procesal Civil Modelo para Iberoamérica (Instituto Chileno de Derecho Procesal, Valparaíso, Edeval), pp. 63-68.

También en: http://cejamericas.org/doc/documentos/CodigoProcesalCivilparaIberoamerica.pdfInstituto.

223 Palomo Vélez, D. (2009), p. 634.

224 Pérez-Ragone, A., Palomo Vélez, D. (2009). "Oralidad y prueba: Comparación y análisis crítico de las experiencias reformadoras del proceso civil en Alemania y España”, en Revista de Derecho (Pontificia Universidad Católica de Valparaíso, Vol. XXXII), pp. 366 y ss.

${ }^{225}$ Esparza Leibar, I. (2007). La instancia de apelación civil. Estudio comparativo entre España y Alemania (dos modelos para el siglo XXI) (Valencia, Ed. Tirant lo Blanch), p. 17. 
amplitud e intensidad que ha caracterizado a las últimas modificaciones, no ha tenido una pacífica aceptación en jueces ni abogados ${ }^{226}$, debido al retroceso de garantías procesales que ha implicado ${ }^{227}$. Concentrando esta breve revisión sólo a lo que dice relación con la reforma introducida a la regulación del recurso de apelación, hay que señalar que lo que se pretendió con la reforma fue un cambio en el modelo que reemplazara el sistema tradicional (de apelación plena) ${ }^{228}$ para dar paso a un sistema de apelación limitada ${ }^{229-230}$. Todavía más, la finalidad de la reforma "es que la apelación deje de ser una segunda instancia con respecto a los hechos, y pase a convertirse, limitando sus objetivos, a controlar la legalidad de la sentencia recaida en la primera instancia" 331 . Se ha buscado "filtrar" al máximo la posibilidad de un examen de los hechos en el tribunal de alzada ${ }^{232}$. Así queda demostrado del parágrafo 529.1, I, de la ZPO, en donde se establece que el tribunal de apelación está ligado fundamentalmente a los hechos fijados por el órgano jurisdiccional que conoció en la primera instancia, punto a partir del cual se intenta conseguir mayor eficacia en la tramitación de la "segunda instancia" problemas de acuerdo a lo que hemos venido sosteniendo a lo largo de este trabajo (desde la perspectiva del contenido y extensión del derecho al recurso), empeora si se tiene presente que entre las reformas introducidas para maximizar la utilidad de los recursos de la Administración de Justicia figura aquella que procura que no sólo en la primera instancia, sino también en la segunda, incluso tratándose de

\footnotetext{
${ }^{226}$ Esparza Leibar, I. (2007), p. 17; García-Rostán Calvín, G. (2001). "Acerca de la ley de reforma de la ordenanza procesal civil alemana de 27 de julio de 2001”, en Revista Tribunales de Justicia (No 4), p. 21.

227 Como lo ha anotado la doctrina, entre los impulsores de estas reformas que buscan la racionalización, racionamiento y limitación de garantías, la cuestión constitucional del debido proceso en general y del derecho al recurso en particular parece ser irrelevante: EsPARZA LeibAR, I. (2007), p. 25. Las voces críticas a la Ley de Reforma han provenido también desde el sector que se mostraba proclive a un cambio restrictivo en materia recursiva. En efecto, se señala que una reforma de carácter restrictivo en sede recursiva exigía un reforzamiento correlativo (más debate, y más esfuerzo en alcanzar una justicia de calidad) de la primera instancia: EsPaRZA LeIBAR, I. (2007), p. 31.

${ }^{228}$ Véase: Eiranova Encinas, E., Lourido Míguez, M. (2001). Código Procesal Civil Alemán (Madrid, Ed. Marcial Pons), pp. 127 y ss.

${ }^{229}$ Esparza Leibar, I. (2007), pp. 19 y 59.

${ }^{230}$ Véase: Pérez-Ragone, A. y Ortiz Pradillo, J. (2006). Código Procesal Civil Alemán (ZPO) (Montevideo, Konrad Adenauer Stiftung, Programa Estado de Derecho para Sudamérica), pp. 282 y ss.

${ }^{231}$ Esparza Leibar, I. (2007), p. 29.

${ }^{232}$ Pérez-Ragone, A. (2005). "El nuevo proceso civil alemán: principios y modificaciones al sistema recursivo", en Revista Iberoamericana de Derecho Procesal (Instituto Iberoamericano de Derecho Procesal, No 7), p. 282.

${ }^{233}$ Esparza Leibar, I. (2007), p. 61.
} 
asuntos en principio atribuidos a un tribunal colegiado, puedan ser resueltos por un juez unipersonal (uno de los miembros de la sala en cuestión), con lo que queda perfectamente claro que los ahorros obtenidos lo son en sacrificio de uno de los elementos que ofrecía mayores garantías de acierto y calidad en la decisión ${ }^{234}$.

\section{V) La propuesta del Proyecto}

a) Oralidad, inmediación y sistema recursivo adoptado en el Proyecto. Toma de posición aún pendiente

El Proyecto de CPC opta, bastante razonablemente (salvo algunas excepciones a las cuales nos hemos referido en otros trabajos), por el modelo procesal civil por audiencias y busca introducir a la Justicia civil, sin excesos ni desbordes puramente dogmáticos, las ventajas que se asocian a la oralidad y sus reglas conexas ${ }^{235}$. Como ya se apuntó al inicio de estas líneas, en lo que se refiere al Proyecto propiamente tal, esta opción hacia la oralidad se refleja no sólo en el Mensaje (No 398-357), sino que también en el hecho de que se recojan expresamente los "principios" de oralidad (art. $7^{\circ}$ ) y sus "principios consecuencia" -inmediación (art. 8º y concentración (art. $9^{\circ}$ ) - y que en la propia regulación de los procedimientos declarativos (ordinario y sumario) quede reflejada la técnica del modelo por audiencias (arts. 64, 65, 252 y ss., 258 y ss.).

En cuanto al tema de la sobrevivencia o no de la segunda instancia, la lectura del articulado propuesto permite constatar que se considera un recurso de apelación en contra de la sentencia del tribunal de primer grado que abre paso a una segunda instancia en donde la revisión del tribunal de alzada alcanza los hechos y el derecho. Con todo, la regulación propuesta presenta particularidades, seguramente producto del debate generado en torno a esta cuestión.

$\mathrm{El}$ art. 334 dispone que:

"El recurso de apelación tiene por objeto obtener del tribunal superior respectivo, que enmiende o revoque conforme a derecho la resolución del inferior, total o parcialmente, con base precisa en los fundamentos de las pretensiones formuladas ante el tribunal inferior".

Hasta aquí nos encontramos con la típica descripción del recurso ordinario de apelación que en la configuración que se propone sería limitada (art. 348), ya que se establece que en segunda instancia no se admitirá prueba alguna, con

${ }^{234}$ García-Rostán Calvín, G. (2001), p. 22.

235 Palomo Vélez, D. (2009), pp. 621 y ss. 
la sola excepción de la documental en determinadas hipótesis ${ }^{236}$. Con todo, acto seguido, el mismo artículo agrega que "podrá alegarse además, o bien exclusivamente, la infracción a normas o garantías procesales cometidas en la primera instancia, para obtener la invalidación del juicio oral y de la resolución respectiva, o solamente de ésta, y ello por las causales especificamente señaladas... ". Se emplea acá una redacción que alude no ya al recurso ordinario de apelación, sino que al recurso extraordinario de nulidad previsto, como se revisó, para el proceso penal y laboral reformados. A las señaladas causales específicas se refiere el art. 336 del Proyecto que en importante medida reproducen la nómina prevista en el art. 374 del CPP.

Si se relaciona esta extraña consagración del recurso de apelación en el Proyecto con la supresión de los recursos de casación (de forma y fondo) para dar lugar a un recurso extraordinario (arts. 353 y ss.), que tiene por objeto que la Corte Suprema unifique la jurisprudencia con ocasión de una sentencia notoriamente injusta para el recurrente, puede concluirse que de lo que se trata realmente es que se ha preferido dejar al legislador una decisión que no se ha podido adoptar por quienes han redactado el Proyecto, esto es, la mantención de la doble instancia en el proceso civil o, derechamente, su reemplazo por un recurso extraordinario de nulidad, con todas las consecuencias que ello apareja ${ }^{237}$. De otra forma no se entiende qué pueden hacer normas propias del recurso extraordinario de nulidad en la regulación propuesta para el recurso ordinario por excelencia: el recurso de apelación.

Con todo, el Proyecto acierta cuando dispone que de todo lo actuado en una audiencia se registrará en imagen y sonido en un formato reproducible (art. 83), puesto que, como ya hemos visto, con la utilización de este recurso tecnológico se salvarían la mayor parte de las objeciones que se plantean a la convivencia de un modelo procesal oral y la segunda instancia.

\section{b) La importancia de una adecuada consagración del mecanismo de ejecución provisional para evitar los problemas asociados a la mala utilización del recurso de apelación}

El reconocimiento de la garantía del derecho al recurso en los términos que se han explicado en este trabajo no se oponen a una medida que ya en otros sitios

\footnotetext{
${ }^{236}$ Esta prueba se podrá aceptar, se precisa, siempre que en concepto del tribunal de alzada resulte verosímil el hecho que la parte que la presenta no haya tenido conocimiento de ella con anterioridad o no haya podido presentarla en la oportunidad legal correspondiente (art. 348).

${ }^{237}$ Trátase de una indefinición que se arrastra desde el Anteproyecto (arts. 345 y ss. y 363 y ss.), en donde, a lo menos, figuraban separados. Véase: Universidad de Chile, "El Anteproyecto de CPC". Revista de Derecho Procesal, Departamento de Derecho Procesal, Facultad de Derecho, No 21, 2008, pp. 102 y ss.
} 
se ha destacado como conveniente y hasta necesaria cuando estamos frente a la implantación de un modelo procesal oral, cual es el potenciamiento del enjuiciamiento realizado en primera instancia (o revalorización de la eficacia de las sentencias dictadas en primera instancia) por la vía de contemplar el mecanismo de la ejecución provisional de las sentencias ${ }^{238}$.

Para que la Justicia civil sea eficaz, y no se prolongue en el tiempo la respuesta a la tutela judicial solicitada, es necesario contemplar ciertos institutos, como el de la ejecución provisional. El caso español muestra bien cómo puede compatibilizarse un sistema que garantiza adecuadamente el derecho al recurso con la recepción de la ejecución provisional. En efecto, la regulación de la ejecución provisional en la LEC española ha supuesto una confianza razonable en la Justicia de Primera instancia, generalizando la ejecutabilidad inmediata de las sentencias, salvo las excepciones legales, sin esperar a que alcancen firmeza, con lo cual se logra acortar el horizonte temporal para que el justiciable reciba una respuesta eficaz a sus demandas de tutela ${ }^{239}$.

La adecuada regulación de este mecanismo en el nuevo CPC puede ser una oportunidad para, sin prescindir de la garantía del derecho al recurso, se busque (como reza la exposición de Motivos de la LEC española) que los jueces dicten sentencias en principio inmediatamente efectivas y no sentencias en principio platónicas, en principio inefectivas. Las sentencias de primera instancia podrían, en este esquema, dejar de ser sólo un paso inicial carente de eficacia práctica ${ }^{240}$, abriéndose mayores oportunidades para dar acogida a una tutela que siendo garantista, también sea provista de posibilidades de ser lo más eficaz posible. Desde luego que ninguna imposición constitucional existe al respecto y se trata sólo de una opción de política legislativa, pero bien vale la pena, a nuestro juicio, aprovechar la reforma procesal civil para incrementar la eficacia de la instancia originaria $^{241}$ que desde la perspectiva del modelo y estructura de trabajo que se

\footnotetext{
${ }^{238}$ Véase: Palomo Vélez, D. y Hinojosa Segovia, R. (2006). "La apuesta de la nueva Ley de Enjuiciamiento Civil española por la revalorización de la importancia del enjuiciamiento de primer grado: La nueva regulación de la ejecución provisional de las sentencias", en Revista Ius et Praxis (Año 12, No 2), pp. 123-162; Meneses Pacheco, C. (2009b). "La ejecución provisional en el proceso civil chileno", en Revista Chilena de Derecho (Pontificia Universidad Católica de Chile, No 1), pp. 21-50.

${ }^{239}$ En todo caso el ejecutado debe poder oponerse a la ejecución provisional con base en la infracción de los presupuestos o requisitos procesales previstos legalmente. Nos inclinamos por la opción que el legislador español ha adoptado respecto de la ejecución provisional pero permitiendo, en los casos de oposición, que el juez tenga ciertas facultades moderadoras, cuando resuelve sobre la oposición del ejecutado, para evitar posibles perjuicios irreparables para ese ejecutado en caso de revocación de la sentencia y no fuera posible la reversión a la situación originaria.

${ }^{240}$ Palomo Vélez, D. (2008), p. 575.

${ }^{241}$ Morello, A. (2001), p. 196.
} 
propone aparece fortalecida, especialmente atractiva como fórmula para evitar la maniobra puramente dilatoria consistente en apelar sistemáticamente las sentencias para diferir una condena casi segura y para especular con la debilidad económica del adversario y de este modo arrancarle una transacción ventajosa ${ }^{242}$. Lamentablemente en este punto, como lo ha destacado la doctrina, el Proyecto es inconsistente y confuso ${ }^{243}$.

\section{Cierre}

De lo expuesto se deben extraer, al menos, las siguientes conclusiones:

1. La decisión legislativa de adoptar el modelo de proceso civil por audiencias, esto es, de introducir la oralidad a la Justicia civil, debe ser materializada sin pretender llevar esta decisión fundamental (ni las decisiones conexas, que ligan con la concentración e inmediación judicial) a un absoluto, como si se trata de principios procesales (y no de meras reglas, como lo son).

2. Las mejores posibilidades de la inmediación judicial efectiva en un proceso oral no alcanzan para sostener que su protección deba traducirse, necesariamente, en la recepción de un sistema recursivo en donde la doble instancia sea suprimida. Se olvida la mayor relevancia que la prueba documental posee en los procesos civiles, en donde la inmediación judicial no incide. Se exageran las ventajas de la inmediación, se ignoran las posibilidades de la grabación audiovisual (inmediación secundaria), configurando una situación por la cual se termina blindando lo resuelto por el juez, con serio perjuicio a la plena revisión por parte del tribunal superior.

3. La tesis que postula la supresión de la doble instancia se sostiene en una lógica que sólo considera la perspectiva del Estado y sus órganos (en este caso, judiciales), privilegiando alivianar su carga de los tribunales de alzada, haciendo retroceder a los justiciables desde la perspectiva del estándar de sus garantías procesales y la aspiración de una decisión más justa, más en un modelo procesal que de momento se decide por aumentar considerablemente los poderes del juez. En otras palabras, de concretarse la supresión de la doble instancia en sede procesal civil, se estará concretando lo que debe evitarse por todo legislador: una reformatio in peius.

4. Junto con tratarse de una propuesta nada razonable, la supresión de la doble instancia para reemplazarla por un recurso extraordinario que se concentre en la

${ }^{242}$ Así se destaca en: Perrot, R. (1982). "La eficacia del proceso civil en Francia", en Ramos Méndez, F. (Dir.) Para un proceso civil eficaz (Barcelona, Universidad Autónoma de Barcelona), p. 197.

${ }^{243}$ Meneses Pacheco, C. (2009b), p. 46. 
revisión del juicio jurídico aparece como contraria al estándar impuesto por la Constitución y los Tratados internacionales de Derechos humanos. De acuerdo a lo dispuesto en ellos, y en especial de conformidad a lo que la Jurisprudencia de la $\mathrm{CIDH}$ ha venido sosteniendo, el derecho al recurso no se satisface de cualquier modo, sino que impone la posibilidad de una revisión lo suficientemente amplia in facto et in iure.

5. La revisión de las decisiones adoptadas en las reformas anteriores (proceso penal, familiar y laboral) evidencia una clara falta de uniformidad en el modelo recursivo que se estima debe imponerse en los sistemas reformados. La revisión de los modelos acogidos en el Derecho comparado (incluido el Código Modelo) muestran una contundente preferencia por la sobrevivencia de la apelación contra la sentencia dictada por el juez de primera instancia (en el marco de procesos orales), sin perjuicio de visualizarse algunos problemas derivados de la limitación que por la vía del funcionamiento o de reformas exhiben algunos países (España y Alemania).

6. La propuesta recogida en el Proyecto de CPC muy claramente refleja la ausencia de acuerdo en la materia. En efecto, bajo el rótulo del "recurso de apelación" se recoge una regulación que contiene un importante número de artículos identificadores del "recurso de nulidad" que se consagra en el proceso penal y laboral. Significa una falta de prolijidad de la propuesta (que también se evidencia en la regulación de otros institutos) difícil de justificar. Siendo sólo una decisión de política legislativa, creemos conveniente que el legislador brinde mayores posibilidades a la reducción del horizonte temporal de la sentencia efectiva (por ser ejecutable) a través de la adecuada regulación del instituto de la ejecución provisional.

\section{BiBLIOGRAFÍA}

Accatino Scagliotti, D. (2006). "La fundamentación de la declaración de hechos probados en el nuevo proceso penal. Un diagnóstico", en Revista de Derecho, Universidad Austral de Chile (Vol. XIX, No 2).

Alcalá-Zamora Castillo, N. (1934). "Notas para la reforma de la ley de Enjuiciamiento Civil", en AA. VV. Estudios de Derecho Procesal (Madrid, Ed. Góngora).

Allorio, E. (1979). "Sul doppio grado del proceso civile", en Studi in onore di Enrico Tulio L. (Milano, Giuffré Editore, T. III).

Alvarado Velloso, A. (2005). Garantismo procesal contra actuación judicial de oficio (Valencia, Ed. Tirant lo Blanch). 
Amrani-MekKi, S. (2008). "El impacto de las nuevas tecnologías sobre la forma del proceso civil”, en CARPI, F. y OrTELls, M. (editores) Oralidad y escritura en un proceso civil eficiente (Valencia, Universidad de Valencia, Tomo I).

Andrés IbÁNEZ, P. (2003). "Sobre el valor de la inmediación (Una aproximación crítica)", en Revista Jueces para la Democracia (No 46).

Andrés IbÁNEz, P. (2007). "Sobre prueba y motivación”, en Revista Jueces para la Democracia (No 59).

Aranguëña Fanego, C. (1994). "Proceso Penal y doble instancia", en Revista Justicia (No 1).

Ariano Deho, E. (2003). "En defensa del derecho de impugnar en el proceso civil (vicisitudes de una garantía incomprendida”, en ARIANO DeHo, E. Problemas del Proceso civil (Lima, Ed. Jurista).

BECEÑA, F. (1933). "Sobre la instancia única o doble en el proceso civil", en Revista de Derecho Privado (No 234).

Berizonce, R. (2004). "La oralidad no es para jueces cómodos, sino al revés", en Revista Sistemas Judiciales (CEJA, No 7).

Bonet Navarro, J. (2009). "Presunción de inocencia a favor del actual recurso de casación", en Revista La Ley Penal (No 64).

Bonet Navarro, J. (2009). La prueba en el proceso civil: cuestiones fundamentales (Madrid, Difusión jurídica).

Calderón Cuadrado, M. Pía (1996). "Breves consideraciones sobre el recurso de apelación y el criterio de doble grado de jurisdicción”, en Revista de Derecho Procesal (No 3).

Calderón Cuadrado, M. Pía (2005). La segunda instancia penal (Pamplona, Ed. Aranzadi).

Calderón Cuadrado, M. Pía (2008). "Quince años de decisiones del Comité de Derechos Humanos de Naciones Unidas. España y el sometimiento de la sentencia penal condenatoria a un tribunal superior", en ARANGÜEÑA FANEGO, C. y Sanz Morán, A. (coordinadores) La reforma de la Justicia Penal: aspectos materiales y procesales (Valladolid, Ed. Lex Nova).

Calderón Cuadrado, M. Pía (2004). "El proceso civil y su estructuración en dos instancias. Problemática que plantea, en Libro homenaje al profesor Dr. D. Eduardo Font Serra (Madrid, Ministerio de Justicia: Centro de Estudios Jurídicos, T. I).

Calderón Cuadrado, M. Pía (2002). "Sobre la exigencia de inmediación en la nueva LEC y su compatibilidad con los recursos ordinarios”, en Revista de Derecho, Universidad de Valencia (No 1). 
Carreras llansana, J. (1962). "El Derecho procesal como arte", en Carreras Llansana, J. y Fenech Navarro, M. Estudios de Derecho procesal (Barcelona, Ed. Bosch).

Cappelletti, M. (1972). La oralidady las pruebas en el proceso civil (Traducc. Santiago Sentís Melendo, Buenos Aires, Ediciones Jurídicas Europa América).

Carocca Pérez, A. (2000). "Recursos en el nuevo sistema procesal penal", en Carocca Pérez, A. y otros Nuevo Proceso Penal (Santiago, Editorial Jurídica ConoSur.

Carocca Pérez, A. (2003). Manual de Derecho Procesal: Los procesos declarativos (Santiago, Ed. LexisNexis, Tomo II).

Carocca Pérez, A. (1997). Derechos Humanos y derecho Civil: Perspectiva procesal (Santiago, Centro de Desarrollo Jurídico Judicial, CPU, Serie Estudios).

Carús Guedes, J. (2003). O principio da oralidade (Sao Paulo, Ed. Revista Dos Tribunais).

Cipriani, F. (2003). "El proceso civil italiano entre eficiencia y garantías", en Batallas por la Justicia civil (Lima, Ed. Cultural Cuzco, Compilación y traducción de Eugenia Ariano Deho).

Chiovenda, J. (1977). Principios de Derecho Procesal Civil (Madrid, Ed. Reus, Tomo II), p. 132.

Coloma Correa, R. (2003). "Panorama general de la prueba en el juicio oral chileno", en AA. VV. La prueba en el nuevo proceso oral (Santiago, Ed. LexisNexis).

Comoglio, L. (2002). "Garantías mínimas del proceso justo civil en los ordenamientos hispano-latinoamericanos", en Revista Iberoamericana de Derecho Procesal (No 2).

Comoglio, L. (2008). "Garantías constitucionales y proceso justo (modelos comparados)", en Revista Peruana de Derecho Procesal (Ed. Communitas, Vol. XI).

Comoglio, L., Ferri, C., Taruffo, M. (2005). Lezioni sul processo civile. I. Il processo ordinario di cognizione, $3^{\text {a }}$ edición (Bologna, Ed. Il Mulino).

Cortés Domínguez, V., Gimeno Sendra, V., Moreno Catena, V. (2003). Derecho Procesal Civil. Parte General, 5a edición (Madrid, Ed. Colex).

Cortéz Matcovich, G. (2006). El recurso de nulidad: doctrina y jurisprudencia (Santiago, Ed. LexisNexis).

Couture, E. (2002). Fundamentos del Derecho Procesal Civil, 4a edición (Buenos aires, Ed. B de F). 
De la Oliva Santos, A. (1997). "El derecho a los recursos. Los problemas de la única instancia”, en Revista Tribunales de Justicia (No 101).

De la Oliva Santos, A. (2009). Casación, oralidad y nuevo proceso civil (tres conferencias chilenas) (Santiago, Ediciones Jurídicas de Santiago).

De la Oliva Santos, A. y otros (2004). Derecho Procesal: Introducción, 3a edición (Madrid, Ed. Universitaria Ramón Areces).

De la Oliva Santos, A. (1996). "Las reformas procesales", en Díez-Picazo GiMÉNEZ, I. (director), Estudios sobre Derecho Procesal (Madrid, Central Hispana, Vol. I).

De las Heras García, M. (2002). "Consideraciones relativas al principio de inmediación en la LEC/2000", en Revista del Poder Judicial (No 6).

De Miguel y Alonso, C. (1975). "El principio de la inmediación dentro del sistema formal de la oralidad", en Boletín Mexicano de Derecho Comparado (Nueva Serie, Año VIII, No 24).

De Souza Laspro, O. (1993) "Oralidade e duplo grau de jurisdicao", en AA. VV. Scritti in onore di Elio Fazzalari (Milano, Ed. Giuffrè, Vol. II, Diritto Processuale Generale).

Del Río Ferretti, C. (2002). "Consideraciones básicas sobre el sistema de prueba en materia penal y control sobre el núcleo fáctico mediante recurso de nulidad (y II)", en Revista Internauta de Práctica Jurídica (No 9).

Del Río Ferretti, C. (2001). "La revisión de los hechos mediante recurso de nulidad”, en AA. VV. Seminario Reforma Procesal Penal (Santiago, Ed. ConoSur-LexisNexis).

Duce, M. y Riego, C. (2007). Proceso penal (Santiago, Ed. Jurídica de Chile).

Herrera AbIÁn, R. (2006). La inmediación como garantía procesal (en el proceso civil y en el proceso penal) (Granada, ed. Comares).

Duce, M., Marín, F. y Riego, C. (2008). "Reforma a los procesos civiles orales: consideraciones desde el debido proceso y calidad de la información”, en Cabezón, A. (coordinador) Justicia Civil: Perspectivas para una reforma en América Latina (Santiago, CEJA).

Eiranova Encinas, E., Lourido Míguez, M. (2001). Código Procesal Civil Alemán (Madrid, Ed. Marcial Pons).

Esparza Leibar, I. (2007). La instancia de apelación civil. Estudio comparativo entre España y Alemania (dos modelos para el siglo XXI) (Valencia, Ed. Tirant lo Blanch).

ETXEBERRÍA GURIDI, J. (2003). Las facultades judiciales en materia probatoria en la LEC (Valencia, Ed. Tirant lo Blanch). 
Fairén Guillén, V. (1988). El Tribunal de Aguas de Valencia y su proceso: Oralidad, concentración, rapidez y economía, 2a edición (Valencia, Ed. Caja de Ahorros de Valencia).

FErrajoli, L. (1996/B). "Los valores de la doble instancia y de la nomofilaquia", en Revista Nueva Doctrina Penal (Ed. Del Puerto).

Ferrer Beltrán, J. (2007). La valoración racional de la prueba (Madrid, Ed. Marcial Pons).

Ferrer Beltrán, J. (2003). "Derecho a la prueba y racionalidad de las decisiones judiciales", en Revista Jueces para la Democracia (No 47).

García-Rostán Calvín, G. (2001). "Acerca de la ley de reforma de la ordenanza procesal civil alemana de 27 de julio de 2001", en Revista tribunales de Justicia (No 4).

Gascón Abellán, M. (2004). Los hechos en el derecho, 2a edición (Madrid, Ed. Marcial Pons).

Gascón InChausti, F. (2008). "Un nuevo instrumento para la tutela de los consumidores y de los créditos transfronterizos: el proceso europeo de escasa cuantía", en Revista Ius et Praxis (Año 14, No 1).

Gimeno Sendra, V. (2008). "La inmediación en la 2a instancia y las sentencias arbitrarias de la primera”, en La Ley (No 6876).

Gómez Martínez, C. (2003). "La grabación del sonido y de la imagen en los juicios civiles: del juez lector al juez espectador" en Revista Jueces para la Democracia (No 48).

González Castro, M. (2004). El derecho al recurso en el Pacto de San José de Costa Rica (Córdoba, Editora Lerner).

GonZÁlez, M. (1998). La segunda instancia en el proceso civil (Barcelona, Ed. Cedecs).

Gorphe, F. (2003). La critica del testimonio (Madrid, Ed. Reus).

GozAínI, O. (2004). "El debido proceso en la actualidad", en Revista Iberoamericana de Derecho Procesal Constitucional (Proceso y Constitución) (Ed. Porrúa, Instituto Iberoamericano de Derecho procesal Constitucional, No 2).

GuASP, J. (1996). La prueba en el proceso civil español: Principios fundamentales (Madrid, Estudio Jurídico Madrid).

Langbein, J. (2002). "La ventaja alemana en el proceso civil", en Revista Iberoamericana de Derecho procesal (No 9, Año VI).

López Blanco, H. (1997). Instituciones de Derecho Procesal Civil Colombiano, 7a edición (Bogotá, Dupre Editores, T. I, Parte General). 
Lorca Navarrete, A. (2007). "La garantía de la oralidad en la exigencia de tutela judicial efectiva civil", en Revista Vasca de Derecho procesal y Arbitraje (Vol. 19, No 3).

Lorca Navarrete, A. (2008). "La garantía procesal del derecho al recurso", en Revista Vasca de Derecho Procesal y Arbitraje (Vol. 20, No 3).

Lorca Navarrete, A. (2000). Tratado de Derecho procesal civil. Parte general: El nuevo proceso civil (Madrid, Ed. Dykinson).

Marinoni, L., Cruz Arenhart, S. (2008). Processo de conhecimento, 7a edición revisada y actualizada (Sao Paulo, Ed. Revista Dos Tribunais).

Martín Brañas, C. (2008). "La oralidad y la segunda instancia civil", en CarPi, F. y Ortells, M. (editores) Oralidad y escritura en un proceso civil eficiente (Valencia, Universidad de Valencia, Tomo I).

Meneses Pacheco, C. (2009a). "La reforma procesal civil en Chile: Observaciones criticas sobre la organización del primer nivel jurisdiccional", en CARRASCO POBLETE, J. (editor) La reforma procesal civil en Chile: Análisis critico del Anteproyecto de CPC (Santiago, Universidad de los Andes, Cuadernos de Extensión Jurídica 16).

Meneses Pacheco, C. (2009b). "La ejecución provisional en el proceso civil chileno", en Revista Chilena de Derecho (Pontificia Universidad Católica de Chile, No 1).

Monroy Gálvez, J. (1996). Introducción al proceso civil (Santa Fe de Bogotá, Ed. Temis, Estudio de Belaunde \& Monroy Abogados).

Montero Aroca, J. (2002). La prueba en el proceso civil, $3^{a}$ edición (Madrid, Ed. Civitas).

Montero Aroca, J.; Flors Matíes, J. (2005). Tratado de recursos en el proceso civil (Valencia, Ed. Tirant lo Blanch).

Montero Aroca, J. (Editor) (2006). Proceso civil e ideologías: Un prefacio, una sentencia, dos cartas y quince ensayos (Valencia, Ed. Tirant lo Blanch).

Montero Aroca, J. (2001). Los principios políticos de la nueva LEC: Los poderes del juez y la oralidad (Valencia, Ed. Tirant lo Blanch).

Morello, A. (2001). "Tendencia moderna hacia el proceso por audiencias", en El proceso civil moderno (La Plata, Librería Editora Platense).

Muñiz Calaf, B. (2002). La segunda instancia en la nueva Ley de Enjuiciamiento Civil (Madrid, Ed. Dykinson).

Nieva Fenoll, J. (2007a). "Los problemas de la oralidad", en Revista Justicia (Nos. 1-2). 
Nieva Fenoll, J. (2007b). "La oralidad en la Ley de Enjuiciamiento Civil: ¿¿Se ha generado superficialidad y precipitación en la elaboración de las resoluciones judiciales?", en Revista Justicia ( $\mathrm{No}_{\text {s. 3-4). }}$

Nieva Fenoll, J. (2008). “The disaventages of orality”, en Carpi, F. y Ortells, M. (editores) Oralidad y escritura en un proceso civil eficiente (Valencia, Universidad de Valencia, Tomo II).

Nogueira Alcalá, H. (1997a). "Los tratados internacionales en el ordenamiento jurídico chileno", en Revista Ius et Praxis (Año 3, No 2).

Nogueira Alcalá, H. (1997b). Dogmática constitucional (Talca, Ed. Universidad de Talca).

Nogueira Alcalá, H. (2007). El debido proceso en la Constitución y el sistema interamericano (Santiago, Ed. Librotecnia).

Nogueira Alcalá, H. (2008). Derechos fundamentales y garantías constitucionales (Santiago, Ed. Librotecnia, Tomo II).

NúñEz OjedA, R. (2007). "Crónica sobre la reforma del sistema procesal civil chileno (fundamentos, historia y principios)", en De la Oliva Santos, A., Palomo Vélez, D. (coordinadores) Proceso civil: Hacia una nueva Justicia civil (Santiago, Ed. Jurídica de Chile).

NúÑEZ OJEDA, R. (2008). "El sistema de recursos procesales en el ámbito civil en un Estado democrático deliberativo", en Revista Ius et Praxis (Año 14, No 1).

Ricci, E. (1978). "Il doppio grado di giurisdizione nel processo civile”, en Rivista di diritto processuale.

Ochoa Moreno, B. (2005). "La implementación de la oralidad en el proceso laboral: debate en torno a la congestión laboral”, en Diálogos de saberes: Investigaciones y Ciencias Sociales (No 23).

Orellana Torres, F. (2008). Comentario al nuevo proceso laboral, 2a edición actualizada (Santiago, Ed. Librotecnia).

Ortells Ramos, M. (2009). Derecho Procesal Civil, 9a edición (Pamplona, Ed. Aranzadi).

Ortells Ramos, M. "Formas del procedimiento y garantías fundamentales del proceso civil". Inédito, se publicará en el Boletín de la Academia de Ciencias Sociales de Venezuela.

Palomo Vélez, D. y Hinojosa Segovia, R. (2006). "La apuesta de la nueva Ley de Enjuiciamiento Civil española por la revalorización de la importancia del enjuiciamiento de primer grado: La nueva regulación de la ejecución provisional de las sentencias", en Revista Ius et Praxis (Año 12, № 2). 
Palomo Vélez, D. (2009). "Las marcas del proceso oral y escrito diseñado en el Proyecto de nuevo CPC”, en Revista Chilena de Derecho (Vol. 36, No 3).

Palomo Vélez, D. (2008). La oralidad en el proceso civil. El nuevo modelo español (Santiago, Ed. Librotecnia).

Palomo Vélez, D. (2007). "La prueba en el proceso civil chileno: ¿Una actividad asumida con suficiente seriedad?, en De la Oliva Santos, A. y Palomo Vélez, D. (coordinadores) Proceso civil: Hacia una nueva Justicia civil (Santiago, Ed. Jurídica de Chile).

Peyrano, J. (2008). "La prueba entre la oralidad y la escritura”, en CarPI, F. y Ortells, M. (editores) Oralidad y escritura en un proceso civil eficiente (Valencia, Universidad de Valencia, Tomo I).

Pereira Anabalón, H. (1965). "La prueba en el recurso de apelación civil”, en Revista de Derecho y Jurisprudencia (No 6).

Pereira Anabalón, H. (1999). "Oralidad e instancia única o doble en el proceso penal”, en Revista Gaceta Jurídica (No 233).

Pereira Campos, S. (2008). El proceso civil ordinario por audiencias: La experiencia uruguaya en la reforma procesal civil. Modelo teórico y relevamiento empirico (Montevideo, Ed. Amalio M. Fernández, CEJA).

Pereira Campos, S. (2002). "El principio de inmediación en el proceso por audiencias: mecanismos legales para garantizar su efectividad”, en Revista internauta de práctica jurídica (No 11).

Pereira Campos, S. (2006). "Una reforma exitosa: la reforma procesal civil en Uruguay” en SiLVA, José Pedro y otros (editores) (Santiago, Libertad y Desarrollo, P. Universidad Católica de Chile y Universidad Autónoma de Madrid).

Pérez-Ragone, A. y Ortiz Pradillo, J. (2006). Código Procesal Civil Alemán (ZPO) (Montevideo, Konrad Adenauer Stiftung, Programa Estado de Derecho para Sudamérica).

Pérez-Ragone, A. (2005). "El nuevo proceso civil alemán: principios y modificaciones al sistema recursivo", en Revista Iberoamericana de Derecho Procesal (Instituto Iberoamericano de Derecho Procesal, No 7).

Pérez-Ragone, A., Palomo Vélez, D. (2009). "Oralidad y prueba: Comparación y análisis crítico de las experiencias reformadoras del proceso civil en Alemania y España”, en Revista de Derecho (Pontificia Universidad Católica de Valparaíso, Vol. XXXII).

Pérez Asenjo, A. (2008). "La valoración de la prueba en segunda instancia", en Picó I Junoy, J. y Lluch, X. (Directores) Aspectos problemáticos en la valoración de la prueba civil (Barcelona, Ed. Bosch). 
Perrot, R. (1982). "La eficacia del proceso civil en Francia", en Ramos Méndez, F. (Dir.) Para un proceso civil eficaz (Barcelona, Universidad Autónoma de Barcelona).

Pfeffer Urquiaga, E. (2001). Código Procesal Penal: Anotado y concordado (Santiago, Ed. Jurídica de Chile).

Picó I Junoy, J. (2008). "El principio de oralidad en el proceso civil español", en Carpi, F. y Ortells, M. (editores) Oralidad y escritura en un proceso civil eficiente (Valencia, Universidad de Valencia, Tomo I,).

PiCó I JunOY, J. (2009). "Valoración de la prueba y segunda instancia civil: Hacia la búsqueda del necesario equilibrio", en Revista Jurídica de Catalunya (No 3).

Pizzorusso, A. (1978). "Sul principio del doppio grado di giurisdizione", en Rivista di Diritto Processuale.

Prieto Castro, L. (1950). "Precisiones sobre la escritura y la oralidad en el Derecho procesal español", en Estudios y comentarios para la teoría y práctica procesal civil (Madrid, Ed. Reus).

Simón, L. (2007). "La prueba entre la oralidad y la escritura", en Revista Uruguaya de Derecho Procesal (No 3).

TARUfFo, M. (2009). "Oralidad y escritura como factores de eficiencia en el proceso civil”, en: Páginas sobre Justicia civil (Madrid, Ed. Marcial Pons).

Alvarado Velloso, A. El debido proceso de la garantía constitucional (Rosario, Ed. Zeus).

TARuffo, M. (2008). La prueba (Madrid, Ed. Marcial Pons).

TARUfFo, M. (2006). "El proceso civil de 'civil law' y el proceso civil de 'common law': aspectos fundamentales" en Sobre las fronteras: escritos sobre la Justicia civil (Bogotá, Ed. Temis).

Taruffo, M. (2002). La prueba de los hechos (Madrid, Ed. Trotta).

Taruffo, M. (2009). "Considerazioni sulle massime d'esperienza”, en Revista Trimestrale di Diritto e Procedura civile (Vol. 63, No 2).

Tavolari Oliveros, R. (2008). "La prueba entre la oralidad y la escritura”, en Carpi, F. y Ortells, M. (editores) Oralidad y escritura en un proceso civil efciente (Valencia, Universidad de Valencia, Tomo I).

Trocker, N. y VArano, V. (Editores) (2005). The reforms of civil procedure in comparative perspective (Torino).

Toro Justiniano, C. (2009). El debido proceso penal: Un estudio desde el prisma de la dogmática procesal penal y la jurisprudencia de la Corte Interamericana de Derechos Humanos (Santiago, Ediciones Jurídicas de Santiago). 
Vallines García, E. (2006). "Sobre la posibilidad de revisar la valoración de las pruebas mediante el recurso de casación penal: estado de la cuestión a la luz del derecho del condenado a la revisión de su sentencia y del principio de inmediación”, en Revista la Ley Penal (No 23).

Vegas Torres, J. (1993). Presunción de inocencia y prueba en el proceso penal (Madrid, Ed. La Ley, Grupo Wolters Kluwer).

VeSCOVI, E. (1988). Los recursos judiciales y demás medios impugnativos en Iberoamérica (Buenos Aires, Ed. Depalma).

VÉSCOVI, E. (1981). "Los principios procesales en el proceso civil latinoamericano", en Boletín Mexicano de Derecho Comparado (Nueva Serie, Año XIV, No 40).

Villalaín Ruiz, E. (1993). "Inmediación procesal o presencia del juez en las actuaciones como el garante de la igualdad de partes", en Cuadernos de Derecho Judicial, Principios constitucionales en el proceso civil, CGPJ.

WaCH, A. (2006). "El sistema de recursos", en Conferencias sobre la Ordenanza procesal civil alemana (Lima, ARA Editores), p. 250.

Walter Díaz, R., Lanata Fuenzalida, G. (2008). Régimen legal del nuevo proceso laboral chileno, $4^{\text {a }}$ edición actualizada (Santiago, Ed. LegalPublishing).

(2008). "Informe del Foro para la reforma procesal civil", en Revista de Derecho Procesal (Facultad de Derecho de la Universidad de Chile, No 21).

(2005). "Propuesta de Bases para redactar un nuevo CPC para la República de Chile", en Revista de Derecho Procesal (Facultad de Derecho de la Universidad de Chile, No 20).

(1994). "Iberoamericano de Derecho Procesal", El Código Procesal Civil Modelo para Iberoamérica (Caracas, Academia de Ciencias Políticas y Sociales, Serie Estudios).

(1989). Proyecto de Código Procesal Civil Modelo para Iberoamérica (Instituto Chileno de Derecho Procesal, Valparaíso, Edeval). 